\title{
Petrochemistry of High-Cr and High-Al chromitites occurrences of Dargai Complex along Indus Suture Zone, Northern Pakistan
}

\author{
${ }^{1}$ Faculty of Earth Resources, China University of Geosciences, Wuhan 4330074, China; *Corresponding author, E-mail: zaheengeo@gmail.com \\ ${ }^{2}$ FATA University, Tribal Subdivision Darra, Kohat 26100, Pakistan \\ ${ }^{3}$ Department of Geological Engineering, BUITEMS, Quetta 87300, Pakistan \\ ${ }^{4}$ School of Earth Sciences and Engineering, Nanjing University, Nanjing 210023, China \\ ${ }^{5}$ Department of Geology, FATA University, Tribal Subdivision Darra, Kohat 26100, Pakistan
}

(Received: July 14, 2019; Revised accepted: November 29, 2019)

https://doi.org/10.18814/epiiugs/2020/020045

The present study has been carried out to determine the chromian spinel and platinum group elements (PGEs) geochemistry of podiform chromitites of Dargai Complex which provides significant information regarding the mantlecrust transition zone (MTZ) to mantle section during the emplacement and genesis of ophiolitic complexes. The mineral chemistry and platinum group elements (PGEs) were analysed using the Electron Probe Micro Analyzer (EPMA) and inductively-coupled plasma mass spectrometer (ICP-MS). Chromian spinels in the high-Cr chromitites (Cr\# >60), harzburgite and mantle dunites have much higher Cr\# values in the range of 78.4 to 81.9, 72.2 to 77.5 and 79.8 to 82.6, respectively. However, the chromian spinels in the high-Al chromitites $(\mathrm{Cr} \#<60)$ and MTZ dunites have much lower Cr\# values in the range of 47.5 to 52.9 and 46.7 to 49.4, respectively. Based on behaviours of $P G E s$, the chemical differences are reflected in these two types of chromitites. The Ir-group (IPGE) concentration is relatively higher than the Pt-group (PPGE) in the high$\mathrm{Cr}$ chromitites, while high-Al chromitites have relatively greater PPGE/IPGE ratios. The melts responsible for the formation of High-Cr chromitites exhibit boninitic affinities, while that of the high-Al chromitites show mid ocean ridges basalt (MORB) signature with hydrous, oxidized and $\mathrm{TiO}_{2}$ poor characteristics. Chromian spinel mineral chemistry and PGE geochemistry data confirm that the coexistence of both types of chromitites in the Dargai Complex may indicate a change in the composition of the parent magma from MORB to boninitic type in a proto fore-arc environment during subduction initiations. This coexistence of compositionally different mantle suites with episodic melting histories in a single ophiolitic complex can be attributed to the mechanically juxtaposition of mantle convection during recycling process within the mantle.

\section{Introduction}

In various ophiolitic complexes, chromitite bodies are randomly distributed within the mantle section and mantle-crust transition zone (MTZ). The composition of chromitites and residual mantle peridotites of ophiolites is sensitive to the nature of reactant magmas and hence can be used to track tectonic setting and melt-peridotites interaction (Dick and Bullen, 1984; Arai, 1992; Zhou and Robinson, 1997; Barnes and Roeder, 2001; Kamenetsky et al., 2001; Arai et al., 2006; Rollinson, 2008; Gonzalez-Jimenez et al., 2011, 2014). Ophiolite display a variety of tectonic settings, from low degree of partial melting at mid ocean ridge (MOR) environments to higher degrees in arc-related settings (Llanes et al., 2015; Fareeduddin and Dilek, 2015). However, the coexistence of both high- $\mathrm{Cr}(\mathrm{Cr} \#>60)$ and high-Al $(\mathrm{Cr} \#<60)$ chromitites with specific composition in the same body of ophiolitic mantle has made their crystallization processes and associated tectonic changes quite debatable (Zhou and Robinson, 1997; Ballhaus, 1998; Ahmed and Arai, 2002; Morishita et al., 2010; Miura et al., 2012; Rollinson and Adetunji, 2013; Xiong et al., 2013; Arai and Miura, 2016).

It is the general consensus that high-Cr chromitites are formed from boninitic magma in a supra-subduction zone (SSZ) settings while highAl chromitites are formed from less refractory tholeiitic magma in a back arc setting or mid ocean ridges (MOR) environments (Zhou et al., 1994; Robinson et al., 1997; Ballhaus, 1998; Ahmed and Arai, 2002; Miura et al., 2012). In some situation, the dual-mode distribution and vertical partitioning have been observed in a given complex due to different degrees of partial melting, with high-Cr chromitites occurring in deeper parts of the mantle section and high-Al chromitites occurring in the MTZ (Roberts and Neary, 1993; Ahmed and Arai, 2002; Gonzalez-Jimenez et al., 2011, 2014). The podiform chromitites have been proposed to be generated at a shallow depth of $<30 \mathrm{~km}$ (Zhou et al., 1994; Zhou and Robinson, 1997; Bao et al., 1999; Rollinson and Adetunji, 2015). The worldwide existence of many unusual minerals including highly reduced and crustal minerals and ultra-high pressure (UHP) minerals in both high-Cr and high-Al chromitites in ophiolites indicate a range of various processes for the formation of chromitites 
Table 1. Representative composition of high-Cr and high-Al chromitites of Dargai Complex through EPMA (wt\%)

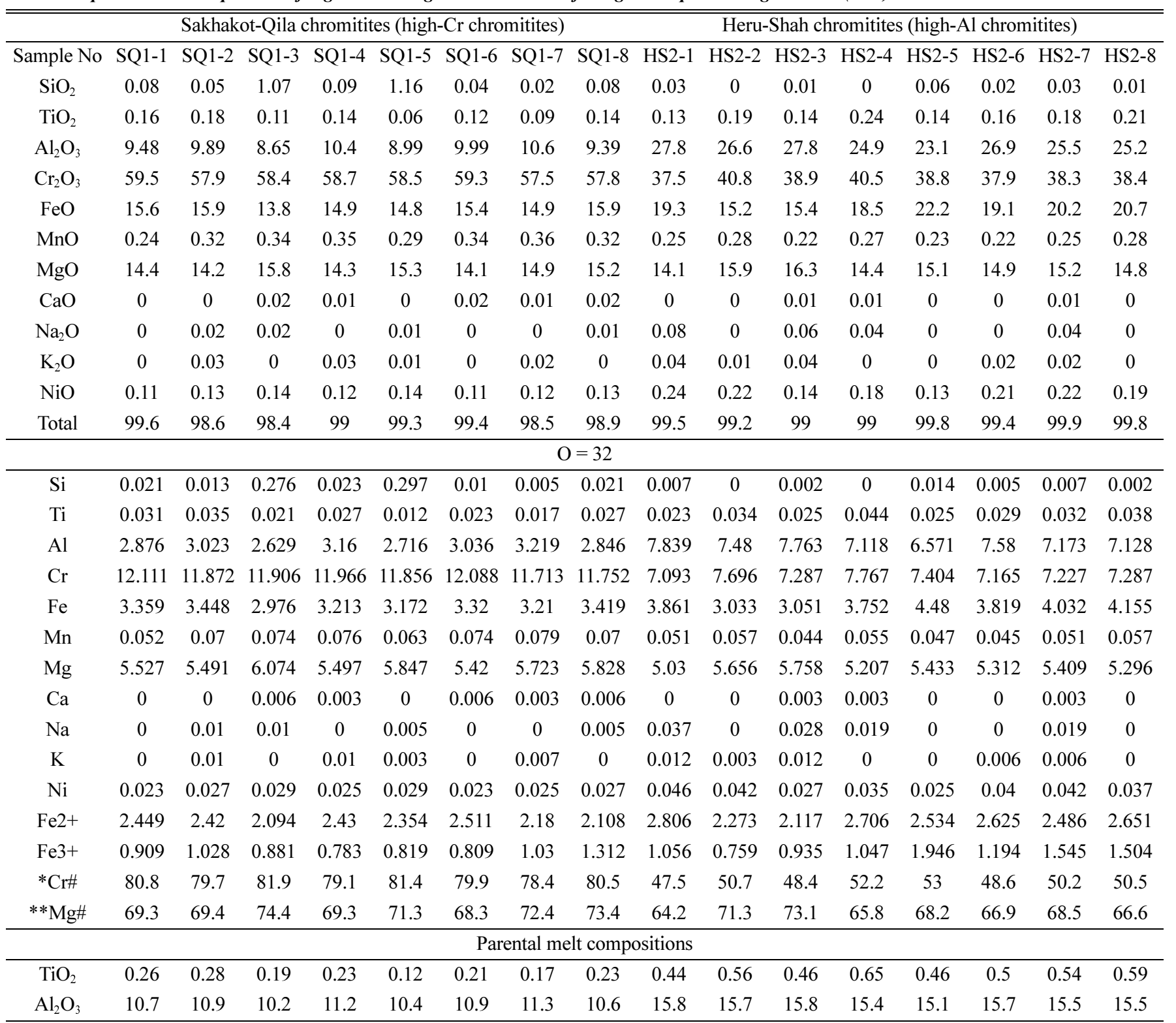

Oxide values in weight percent, chemical formulae calculated on the basis of 32 oxygens, ${ }^{*} \mathrm{Cr} \#=100 \times \mathrm{Cr} /(\mathrm{Cr}+\mathrm{Al}),{ }^{*} \mathrm{Mg} \#=100 \times \mathrm{Mg} /\left(\mathrm{Mg}+\mathrm{Fe}{ }^{2+}\right)$,

EPMA- electron probe micro analyzer.

(Robinson et al., 2004; Yang et al., 2007, 2011, 2014, 2105; Yamamoto et al., 2009; Yazhou et al., 2015; Xiong et al., 2016, 2017; Lian et al., 2017; Wu et al., 2017; Liu et al., 2018). Therefore, genetic relationship of both high-Cr and high-Al chromitites and their formation in a specific tectonic setting is still ambiguous.

Moreover, abundant high-Cr chromitites in Dargai Complex of ophiolitic sequence along Indus Suture Zone also suggest that these ophiolites are formed in a SSZ setting (Ahmed, 1982, 1984; Arif and Jan, 2006). In contrast, detailed field investigations of MTZ of the Dargai Complex suggest that economically significant high-Al chromitites, such as the Heru-Shah chromitites (Table 1), could be considered for the best for exploring the issues stated above. So far a limited data on these chromitites are available, which are restricted to the description of the chromian spinel (Ahmed, 1982, 1984; Arif and Jan, 2006). Based on field observations, petrographic analysis, mineral chemistry and platinum-group elements (PGEs) geochemistry, this study outlines (1) the mineralogy and geochemistry of high-Cr and high-Al chromitites and peridotites, (2) the occurrence and distribution of PGEs within the chromitites and peridotites (harzburgite, mantle dunite and MTZ dunite), and (3) the genesis of the chromitites and possible tectonic setting of their ophiolitic Dargai Complex.

\section{Geological Setting of Dargai Complex}

The Indus Suture Zone (ISZ) marks the northern boundary of IndianPlate with the Asian landmass. But in Pakistan the two plates (i.e., Indian and Karakoram) are separated from each other by exhumed sandwich section of Kohistan Island Arc (KIA) which is formed due to the intra-oceanic subduction of the Neo-Tethys and later on collided 


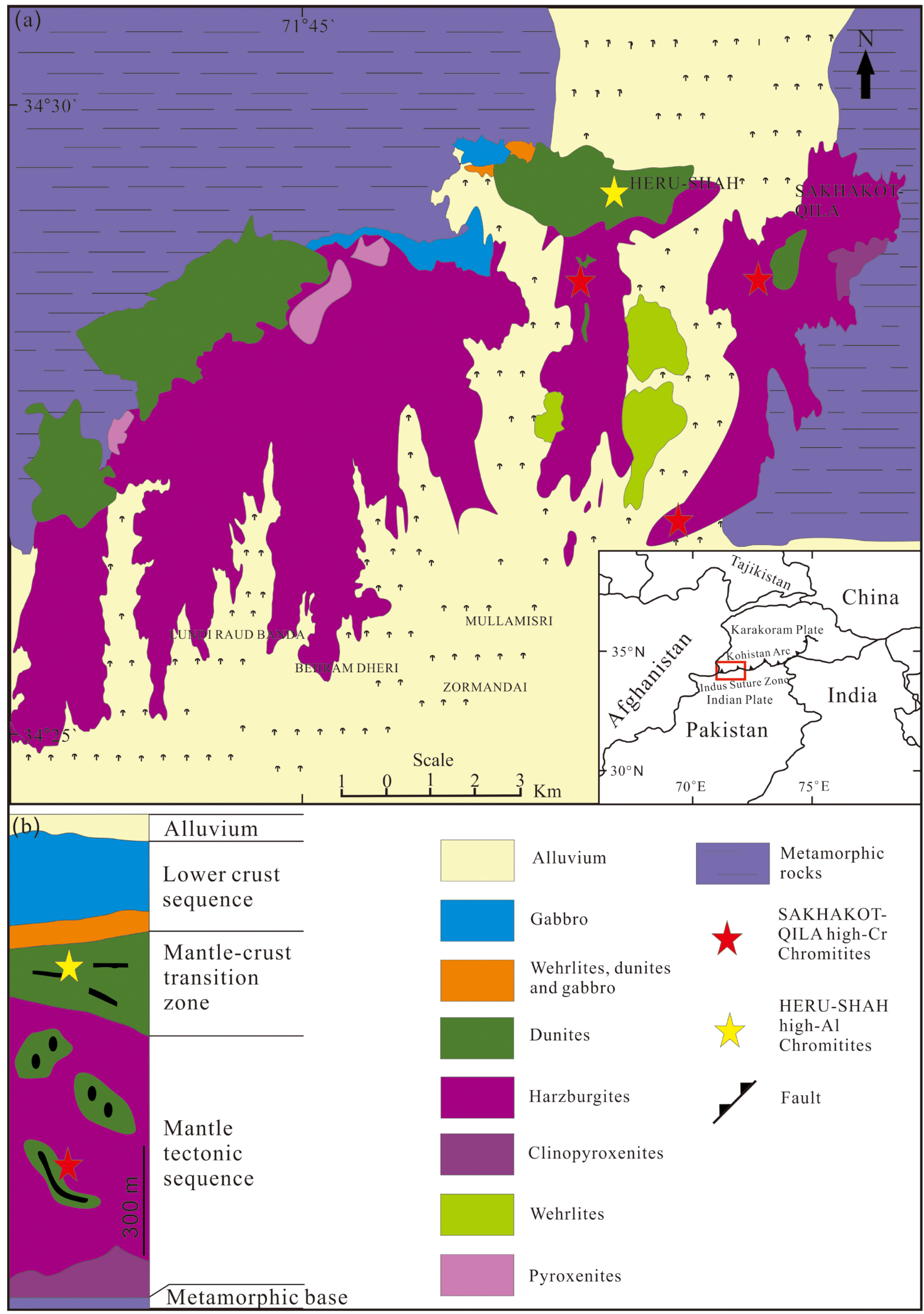

Figure 1. (a) Geological map of the Dargai Complex (Ahmed, 1982, 1984) with some economical grade podiform chromite ore deposits. The small m-set map showing the location of Dargai Complex in north Pakistan (modified after Asrarullah et al., 1979); (b) Compiled geological profile showing rock units of the Dargai Complex modified after Jan et al. (1993), and existences of the Sakhakot-Qila high-Cr chromitites and the Heru-Shah high-Al Chromitites. 
with the Karakoram block (Bard, 1983; Burg et al., 1998; Schaltegger et al., 2002). The Indian plate has northwestern tectonic contact with the southeastern part of Afghan block (Fig. 1a). Both the Indus Suture Zone and western collisional zone with Afghan block contains numerous mafic-ultramafic (ophiolitic) complex (Jan, 1979; Bard, 1983; Miller and Christensen, 1994; Burg et al., 1998; DiPitero et al., 2000; Arif and Jan, 2006). The mafic-ultramafic mélange that occurs along the Indus Suture is known as Dargai Complex (Fig. 1a) which is considered a south-directed thrust fault that was active in the Late Cretaceous age (Kazmi et al., 1984, 1986).

The Dargai Complex is also called as Harichand Ophiolitic Complex (Ahmed, 1982, 1984; Arif and Jan, 2006), which is mainly consisting of southern arcuate mass of ultramafic complex that is extended east to west for $30 \mathrm{~km}$, with an average width of 3 to $6 \mathrm{~km}$. The complex was obducted on metamorphosed pelitics, carbonaceous and calcareous rocks that ranges in age from Precambrian to Triassic (Ahmad et al., 1998). The compositional and textural variations of chromitites and associated phases have been studied in details by Ahmad (1982, 1984). The chromitites in Dargai Complex occur in two horizon based on their occurrences in a southern (lower or Sakhakot-Qila) zone with $\mathrm{Cr} \#>60$, and a northern (upper or Heru-Shah) zone with $\mathrm{Cr} \#<60$ (Fig. 1a). The chemistry of chromite are used to indicate that the high$\mathrm{Cr}$ chromitites are formed in an environment similar to that of suprasubduction zone (SSZ) setting, whereas the high-Al chromitites are crystallized under mid-ocean ridges (MOR) or back arc environment (Robinson et al., 1997; Ballhaus, 1998; Zhou et al., 1998; Ahmed and Arai, 2002; Miura et al., 2012). The ultramafic rocks of Dargai Complex
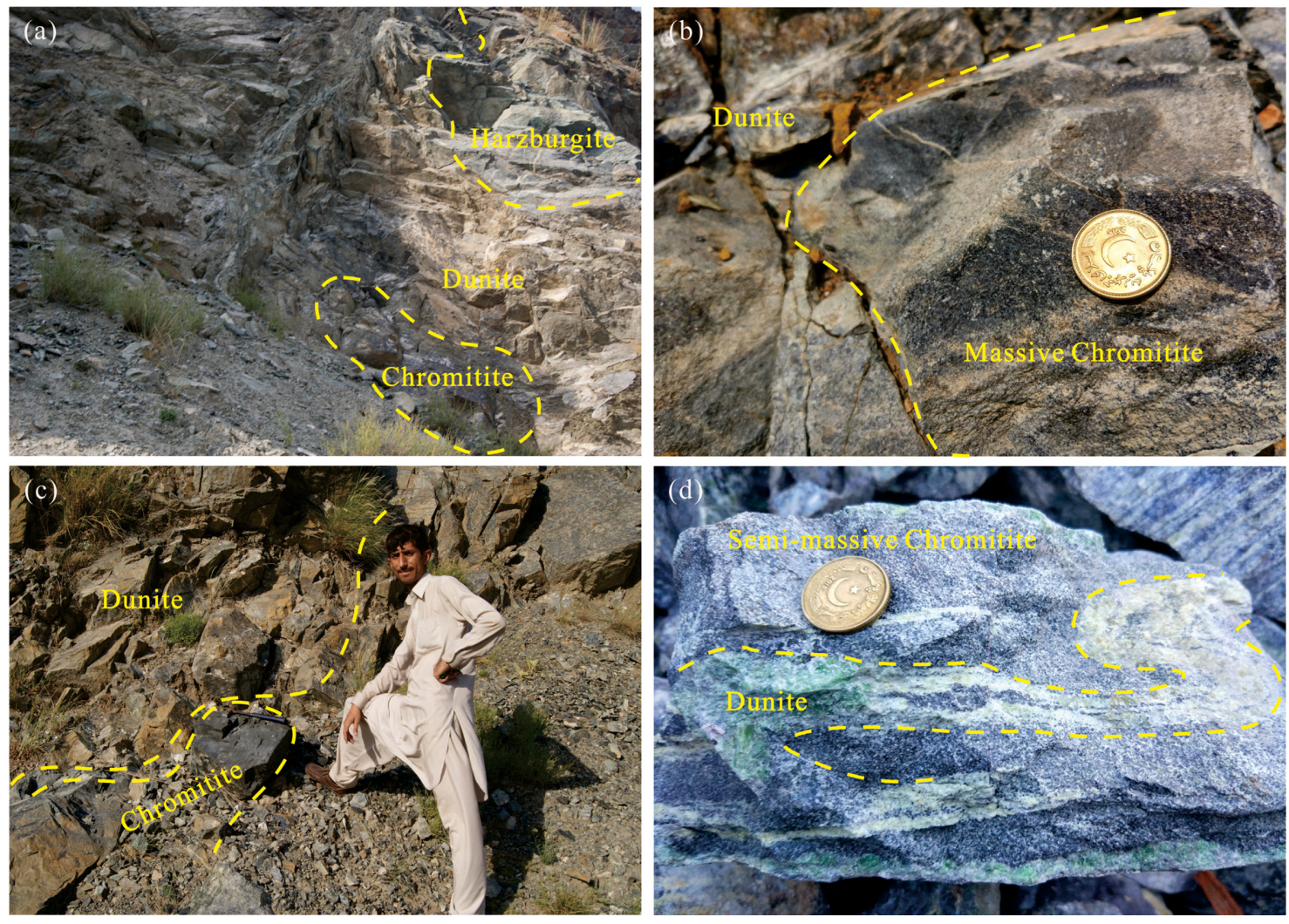

Figure 2. Field photographs showing the relationship between the host rocks and ores in Dargai Complex. (a) Distribution of podiform chromite in the Sakhakot-Qila high-Cr chromitites which are strongly faulted and deformed due to thrusting along the Indus Suture Zone; (b) Massive chromitite body with dunites wall-rock; (c) Gradual transition between Heru-Shah high-Al chromitites and dunites; (d) Various tectonic structures present at the chromite hand specimen of MTZ dunites.
(Fig. 1a) are comprised of $65 \%$ harzburgites, $23 \%$ dunites, $8 \%$ minor bodies of wehrlite, $4 \%$ chromitites and dikes of pyroxenites and serpentinites (Fig. 1a). The dikes of pyroxenite contain mostly clinopyroxene, with less commonly websterite (Asrarullah et al., 1979; Ahmed, 1988).

From the bottom to top (also from east to west), the complex is composed of clinopyroxenite, harzburgites, dunites and widespread bodies of chromitites with a 400 to $600 \mathrm{~m}$ thick zone of extensive dunites (Fig. 1b), which correspond to the mantle-crust transition zone (MTZ) (Asrarullah et al., 1979; Ahmed, 1982, 1984; Jan et al., 1993). There is a sharp contact between the MTZ dunites and harzburgites. The crustal section of the Dargai Complex generally occurs as 1 to $2 \mathrm{~km}$ thick discontinuous outcrops and is mainly represented by gabbro and pyroxenite along its western margins. The lower most part of mafic crustal unit is the top section of the interlayered wehrlites-dunites gabbro with mantle-crust transition zone (Fig. 1b).

In Dargai Complex, the Sakhakot-Qila chromitites hosted in the lenticular bodies of harzburgites and dunite are of mantle origin (Fig. 1b). The large ore bodies of these chromitites are formed as lenses, pods and seams morphologies, with massive, semi-massive and disseminated textures and concordant and folded structures due to the shearing and deformation caused by Main Mantle Thrust (MMT) of Indus Suture Zone (Fig. 2a) (Ahmed, 1982, 1984; Arif and Jan, 2006). The chromitite ore bodies range in thickness from 1 to $10 \mathrm{~m}$, and are usually enclosed by the dunites envelope (Fig. 2b), which are several $\mathrm{cm}$ to $2.5 \mathrm{~m}$ thick. Locally, the host harzburgites have sharp contact with some of the chromitites. The Heru-Shah chromitites are small concordant bodies, which are hosted in the dunites of mantle-crust transition 
zone (MTZ) (Fig. 1b). They are usually fractured and generally from lenticular to rod like bodies (Fig. 2c-d) with nodular and massive textures (Ahmed, 1982, 1984; Jan et al., 1993; Arif and Jan, 2006).

\section{Petrographic Features of Dargai Peridotites and Chromitites}

\section{Harzburgite}

The harzburgite of Dargai Complex mainly consists of olivine (74 to $84 \mathrm{vol} \%$ ), orthopyroxene (14 to $24 \mathrm{vol} \%$ ) with minor clinopyroxene and chromian spinel (Fig. 3a). The textures are mostly porphyroblastic and are characterized by porphyroblasts of olivine and orthopyroxene with plastic deformation features such as, recrystallization, rotation and kink bands. Chromian spinel occurs as inclusions in orthopyroxene as well as in small, euhedral crystals of olivine or along the contacts between these two minerals (Fig. 3a). The orthopyroxene grains show crystal flexing, twin gliding and undulatory extension. Some of the orthopyroxene grains host clinopyroxene exsolution lamellae and also exhibit deformation features along their boundaries (Fig. 3b). There are irregular interstitial grains of clinopyroxene which occur between orthopyroxene and olivine. In
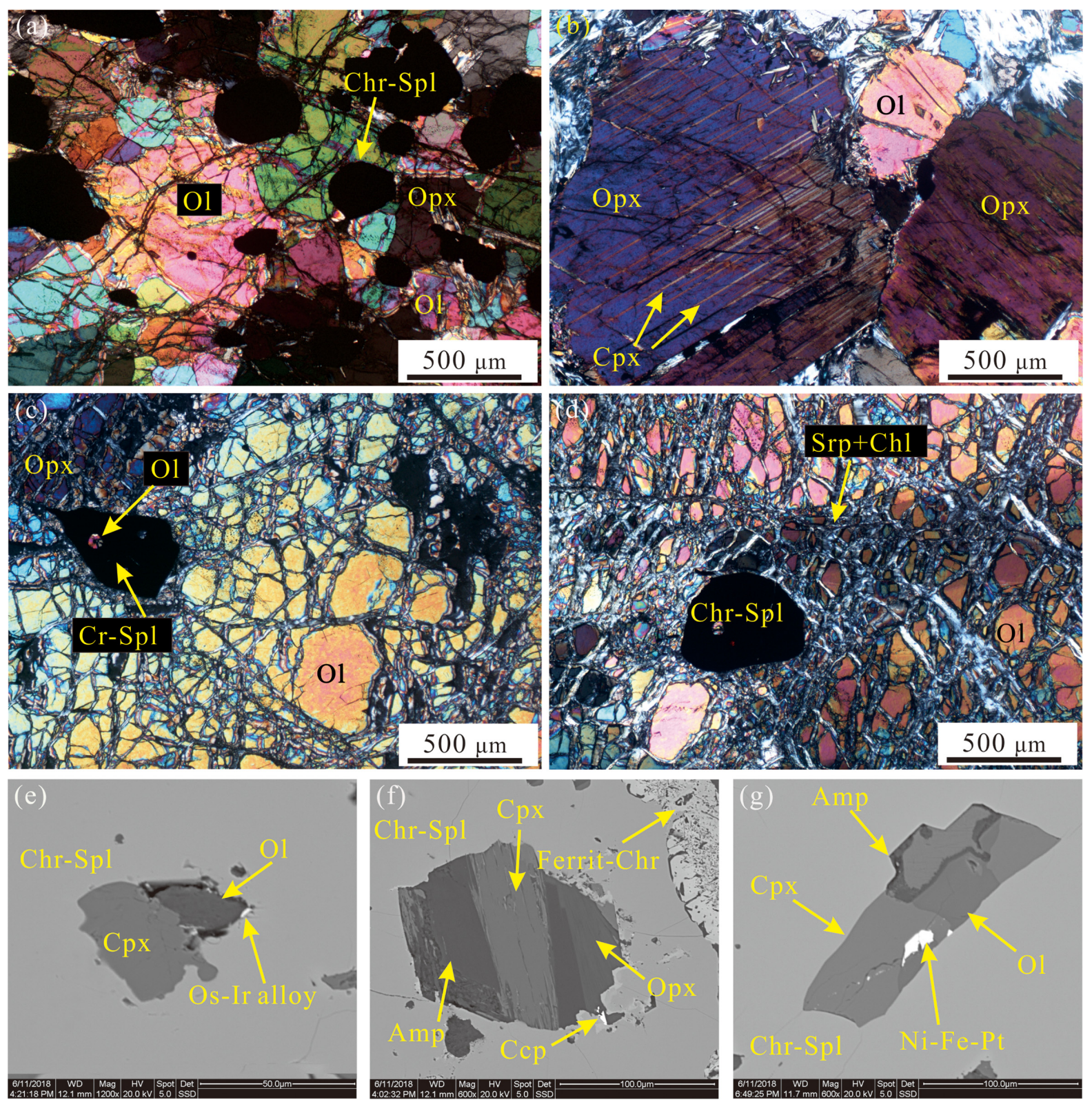

Figure 3. Photomicrographs of representative harzburgites, dunites and chromitites of the Dargai Complex. (a) the fine-grained olivine have contacts with coarse-grained olivines and orthopyroxene (Opx) in harzburgite, (b) orthopyroxene grains having exsolution lamellae of clinopyroxene (Cpx) in the harzburgite, (c) mantle dunites, (d) mantle-crust transition zone (MTZ) dunite, (e) mono or polymineralic inclusions in chromian spinels of Sakhakot-Qila chromitites, (f) chromian spinels of the Heru-Shah chromitites showing alteration to ferrit-chromitites at their boundaries and cracks, (g) polymineralic inclusions occur in the chromian spinels of Heru-Shah chromitites which include amphibole (Amp), Opx, Cpx, and Ni-Fe-Pt alloy. Olivine (Ol), clinopyroxene (Cpx), orthopyroxene (Opx), chromian spinel (Cr-spl), serpentine (Srp), chlorite (Chl), ferrit chromite (Ferrit-Chr), amphibole (Amp), chalcopyrite (Ccp). 
harzburgite, the residual chromian-spinel grains are brown to reddish-brown in color and smaller in size which mostly occurs as interstitial grains along the triple junctions of olivine grains. The harzburgites are mostly fresh with only sparse cracks occupied by chlorite and serpentine. Exsolution lamellae and kink deformation characteristics in harzburgites show that these rocks were originally shaped at mantle pressures and temperatures.

\section{Mantle Dunite and MTZ Dunite}

Mechanical properties such as crystal growth, deformation and qualitative description of texture provide significant information about the geotectonic nature of rocks (Esmailzadeh et al., 2017; Ahmadi et al., 2018). Mantle dunites in the harzburgites occur as lenses which extensively consist of granular olivine (93 to $97 \mathrm{vol} \%$ ) with minor clinopyroxene and chromian spinel (Fig. 3c). The olivine crystals are 0.2 to $1 \mathrm{~mm}$ in diameter and show deformational twinning and wavy extinction. Some of the large crystals have been intensively fractured (Fig. 3c). Clinopyroxene occurs as small $(0.2$ to $0.4 \mathrm{~mm})$ euhedral crystals. The chromium spinel grains ( 0.1 to $0.4 \mathrm{~mm}$ ) are generally distributed in the olivine, but their local concentration is high enough to form disseminated-chromitites. Chromian is an important element in helping to determine the conditions that rocks, soil and ophiolite form (Kyere et al., 2018). Chromian spinel in the studied dunites hosting high-Cr chromitites are largely anhedral in shape (Fig. 3c), while chromian spinel in dunites, enclosing high-Al chromitites, are predominantly euhedral or subhedral in shape (Fig. 3d). This is in consistence with the observations of Matsumoto and Arai (2001).

The MTZ dunites have a granular texture (Fig. 3d) similar to that of mantle dunites but it is characterized by weak bands or layers which have been obliterated by massive hydrothermal alteration. Chlorite and serpentine are formed along the cracks and grain borders by alteration, eventually leading to small "island" of olivine relicts (Fig. 3d). The chromian spinel grains are weakly directed parallel to bandings in the MTZ dunites (Fig. 2d).

\section{Chromitites}

Chromitites is chromite deposit, which is composed of chromite and silicate minerals, such as olivine, pyroxene. Chromium element of chromite and other heavy metals have great importance in industrial manufacturing and also in our daily life (Arasaretnam and Kirudchayini, 2019; Nkansah et al., 2018). The textures of chromitites of Sakhakot-Qila Dargai Complex are primarily massive, but merge into disseminated types when reaches to the mantle dunite contacts. Massive chromitites usually contain $>94$ vol $\%$ chromian spinel grains, which are coarse grained (1 to $5 \mathrm{~mm}$ ) and are typically anhedral to subhedral in shape. The olivine, chlorite and serpentine are the inter-granular minerals with small amount of base metal sulfides. The disseminated chromitites with $\leq 40 \mathrm{vol} \%$ chromian spinel grains occur at the edges of massive chromitites which form irregular patches of few centimeters to a few meters across. Disseminated chromitites consist of variable amounts of chromian spinel and olivine. The size of spinel in these rocks is smaller (0.5-1 $\mathrm{mm}$ in diameter) than those of massive chromitites. Chromian spinel grains in both chromitites consist of inclusions of silicates, platinum-group minerals (PGM) and base metal sulfide (BMS). Clinopyroxene and olivine are the most common silicates inclusions which are present in the chromian spinel as monomineralic grains with rounded-subhedral shape, while they can also be associated as poly-mineralic and with base metal sulfide (Fig. 3e). The base metal sulfides are mainly chalcopyrite, millerite and pentlandite. The chromian spinel contains anhedral inclusions of Os-Ir alloys along with the BMS (Fig. 3e).

The chromitites of Heru-Shah Dargai Complex are generally characterized by semi-massive textures, with predominance of disseminated to nodular textures near the contact with the host mantlecrust transition zone (MTZ) dunite. As compared to Sakhakot-Qila chromitites these varieties are considerably more altered and occur at deeper levels in the mantle section. The chromian spinel grains are altered to ferrit chromite along the margins and cracks (Fig. 3f), whereas the olivine present along the boundaries of chromian spinel grains are replaced by the serpentine with chlorite bands along the rims. The chromian spinel crystals have abundant solid poly-mineralic inclusions ranging in size from 5 to $100 \mu \mathrm{m}$ in size. These inclusions mainly consist of amphibole, clinopyroxene and orthopyroxene with minor olivine, base metal sulfide (BMS) and platinum-group minerals (PGM). The amphibole and orthopyroxene inclusions are associated with some nickel-iron-platinum (Ni-Fe-Pt) alloys (Fig. $3 f-g)$.

\section{Analytical Methods}

A total number of 30 fresh samples were collected which include 8 chromitites from Sakhakot-Qila, 8 peridotites from Heru-Shah, 5 harzburgites, 5 mantle dunites and 4 MTZ dunites from the Dargai Complex. These samples were collected for mineral geochemistry and whole rock platinum group elements (PGE) composition. The chromian spinel and associated silicate minerals were analyzed for major elements, after the preparation of polished thin sections, by JEOL JXA-8100 Electron Probe Micro Analyzer (EPMA) equipped with four wavelength-dispersive spectrometers (WDS) in the State Key Laboratory of Geological Processes and Mineral Resources, China University of Geosciences (Wuhan). The analysing parameters of EPMA were accelerating voltage of $15 \mathrm{kV}$, beam current of $20 \mathrm{nA}$ and a beam diameter of $1 \mu \mathrm{m}$ size. Natural and synthetic standards were used to check calibration precision of the instrument. By assuming the ideal chromian spinel stoichiometry of $\mathrm{A}^{2+} \mathrm{B}^{3+}{ }_{2} \mathrm{O}_{4}$ the amount of $\mathrm{Fe}^{3+}$ in chromite were calculated and the results of chromian spinel and silicates representative analysis are given in Tables 1 to 5 .

The PGE concentration of the chromitites and peridotites were determined at the Institute of Geochemistry, Chinese Academy of Sciences by adopting nickel-sulfide fire assay and Te-coprecipitation method followed by inductively-coupled plasma mass spectrometry (ICP-MS) measurements (Jackson et al., 1990; Sun et al., 1993). A standard sample (GBW079290) was used as a PGE reference to clarify the consistency of analytical results. The accuracies of the analysis were enhanced than $5 \%$ for Ir, Rh, and Pd, and $10 \%$ for the $\mathrm{Os}$, Ru, Pt elements. The detection limits for PGEs and results of representative analyses are given in Table 6. For detail procedures see the technique of Liang et al. (2000) and Sun and Sun (2005) and summary of the research methodology displayed in Figure 4. 


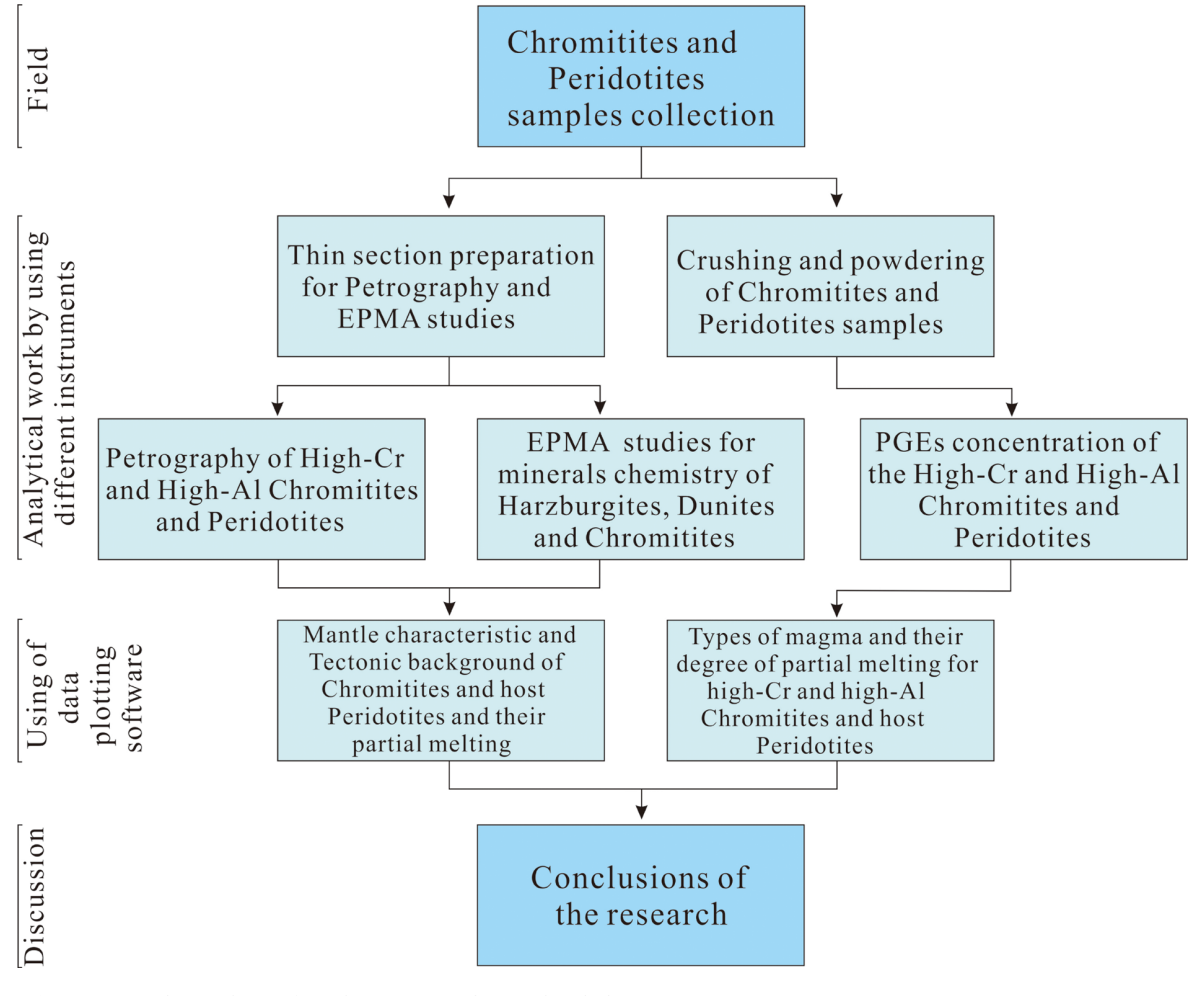

\section{Results}

\section{Mineral Chemistry}

The probe analyses were carried out on chromian spinels and silicates after preparation of polished thin sections of chromitites and enclosed dunite and host harzburgite. The chemical composition of Sakhakot-Qila chromian spinel is particularly different as compared to that of Heru-Shah. The $\mathrm{Cr}_{2} \mathrm{O}_{3}$ contents of Sakhakot-Qila chromian spinels are in the range of 57.5-59.5 wt $\%$ and $\mathrm{Al}_{2} \mathrm{O}_{3}$ from 8.65$10.6 \mathrm{wt} \%$, whereas in the Heru-Shah chromitites $\mathrm{Cr}_{2} \mathrm{O}_{3}$ contents vary from 37.5 to $40.8 \mathrm{wt} \%$ and $\mathrm{Al}_{2} \mathrm{O}_{3}$ from 23.1 to $27.8 \mathrm{wt} \%$. The $\mathrm{Cr} \#$ values are ranging from 78.4 to 81.9 and 47.5 to 52.9 in chromian spinel and chromitites ore of Sakhakot-Qila and Heru-Shah, respectively (Fig. 5a; Table 1). Thus these chromitites are classified as High-Cr metallurgical and high$\mathrm{Al}$ refractory chromitites. The high-Cr types spinels have 69.3 to $74.4 \mathrm{Mg}$ and 0.06 to 0.18

Figure 4. Flow chart for the research methodology.
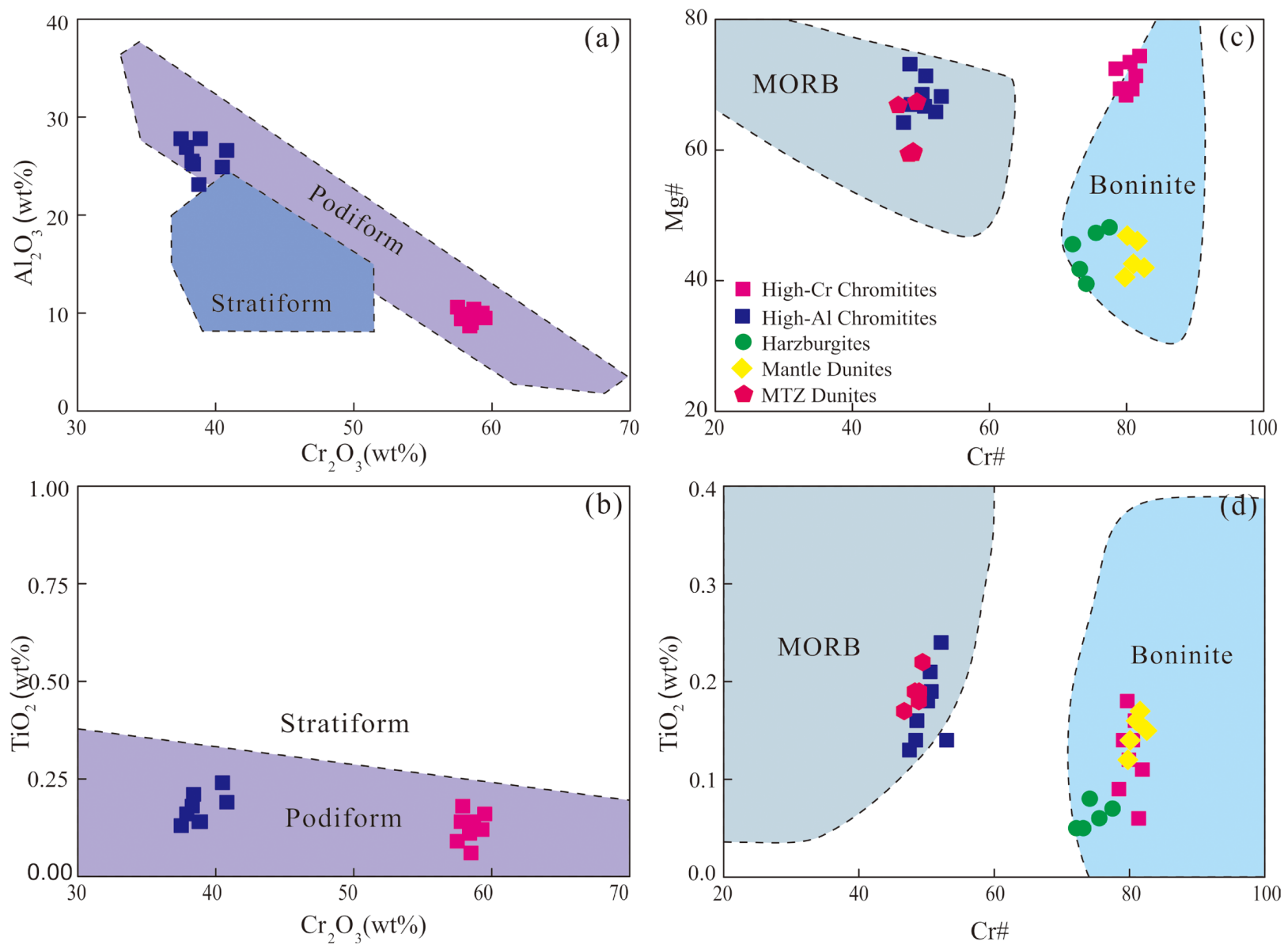

Figure 5. (a) Chemical composition of chromian spinel from chromitites and peridotites plotted on $\mathrm{Al}_{2} \mathrm{O}_{3}$ various $\mathrm{Cr}_{2} \mathrm{O}_{3}$ diagram, (b) $\mathrm{TiO}_{2}$ versus $\mathrm{Cr}_{2} \mathrm{O}_{3}$ diagram, (c) $\mathrm{Cr} \#$ versus $\mathrm{Mg} \#$ diagram, (d) $\mathrm{Cr} \#$ versus $\mathrm{TiO}_{2}$ diagram. Fields for the stratiform and podiform chromite are taken from Uysal et al. (2009b), while boninitic and mid ocean ridges basalt (MORB) fields are from Dick and Bullen (1984) and Arai (1992). 
$\mathrm{wt} \% \mathrm{TiO}_{2}$ contents, whereas the $\mathrm{Mg} \#$ values (64.2-73.1) are slightly lower in high-Al chromitites with $\mathrm{TiO}_{2}$ contents 0.13 to $0.24 \mathrm{wt} \%$ (Fig. 5b-c; Table 1). The Cr\# vs. Mg\# values in chromian spinel and $\mathrm{Cr} \#$ vs. $\mathrm{TiO}_{2}$ values in the chromitites (high-Cr chromitites) of the Sakhakot-Qila plot in the boninitic field, while the Heru-Shah chromitites (high-Al chromitites) partially fall in the field of MORB (Fig. $5 c-d)$.

The mantle dunite chromian spinels have similar or somewhat higher $\mathrm{Cr} \#(79.8-82.6)$ and $\mathrm{TiO}_{2}(0.12$ to $0.17 \mathrm{wt} \%)$ as compared to that of the high-Cr chromitites (Fig. 5c-d; Table 2). The MTZ dunites have much lower $\mathrm{Cr} \#$ values in the chromian spinels (46.7 to 49.4) but higher Mg\# values (59.4 to 67.3) than those of mantle dunite chromian spinels (Fig. 5c). The Cr\# and Mg\# contents of chromian spinels of MTZ dunites are comparable or slightly lower than those in the high$\mathrm{Al}$ chromitites, but are having slightly higher contents of $\mathrm{TiO}_{2}(0.17$ to $0.22 \mathrm{wt} \%$ ) than those of mostly occurring in the high-Al chromitites and mantle dunites (Fig. 5d).

The Cr\# values are ranging from 72.2 to 77.5 in the chromian spinels of harzburgites which are lower than those of high-Cr chromitites and mantle dunites. The increasing trend of $\mathrm{Cr} \#$ values is also accom- panied by an increase in the $\mathrm{TiO}_{2}$ concentration from the host harzburgite to mantle dunite and then to high-Cr chromitites; which is $<0.08$ $\mathrm{wt} \%$ in chromian spinel of harzburgite, 0.12 to $0.17 \mathrm{wt} \%$ in chromian spinel of mantle dunite and 0.06 to $0.18 \mathrm{wt} \%$ in those of high-Cr chromitites (Fig. 5d).

Forsterite (Fo) contents of olivines in the harzburgites are ranging from 88.6 to 89.6 with $\mathrm{NiO}$ concentration between 0.24 to $0.35 \mathrm{wt} \%$, whereas the Fo contents in the mantle dunites are slightly higher with a range of 90.0 to 91.9 and $\mathrm{NiO}$ contents are ranging from 0.37 to 0.44 wt $\%$. The Fo values of MTZ dunite olivines are between 88.8 to 89.8 with a range of 0.36 to $0.44 \mathrm{wt} \% \mathrm{NiO}$ contents. High-Cr chromitites and high-Al chromitites olivine grains have high Fo contents ranging from 94.2 to 95.1 and 88.4 to 91.8 , respectively (Table 3 ).

All of the studied clinopyroxenes are diopside (Fig. 6a), but they have relatively different contents of $\mathrm{Cr}_{2} \mathrm{O}_{3}, \mathrm{TiO}_{2}$ and $\mathrm{MgO}$ (Fig. 6b-c). In harzburgite, the clinopyroxenes have greater amount of $\mathrm{Cr}_{2} \mathrm{O}_{3}$ which is varying from 0.39 to $0.58 \mathrm{wt} \%$ and $\mathrm{Al}_{2} \mathrm{O}_{3}$ from 0.74 to $1.16 \mathrm{wt} \%$ while the mantle dunites clinopyroxenes have $\mathrm{Cr}_{2} \mathrm{O}_{3}$ and $\mathrm{Al}_{2} \mathrm{O}_{3}$ contents in the range of 0.16 to $0.18 \mathrm{wt} \%$ and 0.16 to $0.17 \mathrm{wt} \%$, respectively. The high-Cr chromitites interstitial clinopyroxenes contain lowest $\mathrm{Al}_{2} \mathrm{O}_{3}$

Table 2. Representative composition of chromian spinel in Dargai Complex peridotites through EPMA (wt\%)

\begin{tabular}{|c|c|c|c|c|c|c|c|c|c|c|c|c|c|c|c|}
\hline \multirow[b]{2}{*}{ Sample No } & \multicolumn{5}{|c|}{ Harzburgite } & \multicolumn{5}{|c|}{ Mantle Dunite } & \multicolumn{5}{|c|}{ MTZ Dunite } \\
\hline & SQ4-1 & SQ4-2 & SQ4-3 & SQ4-4 & SQ4-5 & SQ5-1 & SQ5-2 & SQ5-3 & SQ5-4 & SQ5-5 & HS4-1 & HS4-2 & HS4-3 & HS44 & HS4-5 \\
\hline $\mathrm{SiO}_{2}$ & 1.19 & 1.27 & 1.25 & 1.08 & 1.17 & 0.03 & 0.04 & 0.01 & 0 & 0 & 0.01 & 0 & 0.03 & 0.02 & 0 \\
\hline $\mathrm{TiO}_{2}$ & 0.08 & 0.05 & 0.07 & 0.05 & 0.06 & 0.12 & 0.15 & 0.14 & 0.17 & 0.16 & 0.17 & 0.19 & 0.22 & 0.18 & 0.19 \\
\hline $\mathrm{Al}_{2} \mathrm{O}_{3}$ & 12.8 & 13.2 & 10.6 & 13.9 & 11.7 & 9.56 & 8.22 & 9.06 & 8.87 & 8.96 & 27.5 & 25.6 & 24.1 & 25.9 & 26.1 \\
\hline $\mathrm{Cr}_{2} \mathrm{O}_{3}$ & 54.8 & 53.7 & 54.5 & 53.7 & 53.9 & 56.2 & 58.1 & 54.4 & 58.5 & 56.9 & 35.9 & 36.5 & 35.1 & 36.9 & 36.3 \\
\hline $\mathrm{FeO}$ & 21.9 & 22.5 & 21.7 & 20.8 & 22.3 & 25.6 & 24.9 & 24.9 & 22.1 & 24.5 & 20.5 & 23.9 & 25.2 & 23.4 & 23.8 \\
\hline $\mathrm{MnO}$ & 0.41 & 0.36 & 0.39 & 0.41 & 0.38 & 0.35 & 0.37 & 0.42 & 0.39 & 0.41 & 0.26 & 0.27 & 0.25 & 0.27 & 0.24 \\
\hline $\mathrm{MgO}$ & 8.21 & 8.78 & 9.99 & 9.58 & 9.91 & 8.01 & 8.33 & 9.13 & 9.05 & 8.37 & 14.8 & 13.1 & 14.9 & 13.2 & 13.1 \\
\hline $\mathrm{CaO}$ & 0 & 0 & 0 & 0 & 0 & 0.01 & 0 & 0.02 & 0.02 & 0.02 & 0.01 & 0 & 0.01 & 0 & 0 \\
\hline $\mathrm{Na}_{2} \mathrm{O}$ & 0.01 & 0.04 & 0.02 & 0 & 0.01 & 0.04 & 0 & 0.06 & 0.04 & 0.03 & 0.07 & 0 & 0.05 & 0 & 0 \\
\hline $\mathrm{K}_{2} \mathrm{O}$ & 0 & 0 & 0 & 0.01 & 0.01 & 0.01 & 0 & 0.01 & 0.01 & 0 & 0.01 & 0 & 0.01 & 0 & 0.01 \\
\hline $\mathrm{NiO}$ & 0.09 & 0.02 & 0.08 & 0.11 & 0.09 & 0.05 & 0.05 & 0.08 & 0.07 & 0.06 & 0.19 & 0.16 & 0.17 & 0.19 & 0.21 \\
\hline Total & 99.5 & 99.9 & 98.6 & 99.6 & 99.5 & 99.9 & 100.2 & 98.2 & 99.2 & 99.4 & 99.42 & 99.7 & 100 & 100.1 & 99.9 \\
\hline \multicolumn{16}{|c|}{$\mathrm{O}=32$} \\
\hline $\mathrm{Si}$ & 0.315 & 0.333 & 0.332 & 0.282 & 0.307 & 0.008 & 0.011 & 0.003 & 0 & 0 & 0.002 & 0 & 0.007 & 0.005 & 0 \\
\hline $\mathrm{Ti}$ & 0.016 & 0.01 & 0.014 & 0.01 & 0.012 & 0.024 & 0.03 & 0.028 & 0.034 & 0.032 & 0.03 & 0.035 & 0.04 & 0.033 & 0.034 \\
\hline $\mathrm{Al}$ & 3.994 & 4.075 & 3.318 & 4.27 & 3.618 & 3.018 & 2.602 & 2.886 & 2.809 & 2.844 & 7.727 & 7.311 & 6.81 & 7.364 & 7.426 \\
\hline $\mathrm{Cr}$ & 11.47 & 11.121 & 11.445 & 11.066 & 11.181 & 11.901 & 12.336 & 11.623 & 12.43 & 12.116 & 6.767 & 6.993 & 6.653 & 7.038 & 6.928 \\
\hline $\mathrm{Fe}$ & 4.848 & 4.928 & 4.82 & 4.533 & 4.893 & 5.734 & 5.592 & 5.627 & 4.967 & 5.518 & 4.087 & 4.843 & 5.052 & 4.721 & 4.804 \\
\hline $\mathrm{Mn}$ & 0.092 & 0.08 & 0.088 & 0.091 & 0.084 & 0.079 & 0.084 & 0.096 & 0.089 & 0.094 & 0.052 & 0.055 & 0.051 & 0.055 & 0.049 \\
\hline $\mathrm{Mg}$ & 3.241 & 3.429 & 3.956 & 3.723 & 3.877 & 3.199 & 3.335 & 3.679 & 3.626 & 3.361 & 5.26 & 4.733 & 5.326 & 4.748 & 4.715 \\
\hline $\mathrm{Ca}$ & 0 & 0 & 0 & 0 & 0 & 0.003 & 0 & 0.006 & 0.006 & 0.006 & 0.003 & 0 & 0.003 & 0 & 0 \\
\hline $\mathrm{Na}$ & 0.005 & 0.02 & 0.01 & 0 & 0.005 & 0.021 & 0 & 0.031 & 0.021 & 0.016 & 0.032 & 0 & 0.023 & 0 & 0 \\
\hline $\mathrm{K}$ & 0 & 0 & 0 & 0.003 & 0.003 & 0.003 & 0 & 0.003 & 0.003 & 0 & 0.003 & 0 & 0.003 & 0 & 0.003 \\
\hline $\mathrm{Ni}$ & 0.019 & 0.004 & 0.017 & 0.023 & 0.019 & 0.011 & 0.011 & 0.017 & 0.015 & 0.013 & 0.036 & 0.031 & 0.033 & 0.037 & 0.041 \\
\hline $\mathrm{Fe}^{2+}$ & 4.969 & 4.789 & 4.265 & 4.448 & 4.322 & 4.692 & 4.611 & 4.163 & 4.25 & 4.528 & 2.61 & 3.215 & 2.582 & 3.198 & 3.224 \\
\hline $\mathrm{Fe}^{3+}$ & 0.121 & 0.139 & 0.555 & 0.085 & 0.571 & 1.041 & 0.981 & 1.464 & 0.716 & 0.99 & 1.477 & 1.627 & 2.47 & 1.523 & 1.581 \\
\hline$* \mathrm{Cr} \#$ & 74.2 & 73.2 & 77.5 & 72.2 & 75.6 & 79.8 & 82.6 & 80.1 & 81.6 & 80.9 & 46.7 & 48.9 & 49.4 & 48.9 & 48.3 \\
\hline$* * \mathrm{Mg} \#$ & 39.5 & 41.7 & 48.1 & 45.6 & 47.3 & 40.5 & 41.9 & 46.9 & 46 & 42.6 & 66.8 & 59.5 & 67.4 & 59.8 & 59.4 \\
\hline
\end{tabular}

Oxide values in weight percent, chemical formulae calculated on the basis of 32 oxygens, ${ }^{*} \mathrm{Cr} \#=100 \times \mathrm{Cr} /(\mathrm{Cr}+\mathrm{Al}),{ }^{* *} \mathrm{Mg} \#=100 \times \mathrm{Mg} /\left(\mathrm{Mg}+\mathrm{Fe}{ }^{2+}\right)$. 
Table 3. Representative composition of olivine in Dargai Complex peridotites and chromitites through EPMA (wt\%)

\begin{tabular}{|c|c|c|c|c|c|c|c|c|c|c|c|c|c|c|}
\hline Lithology & S. No & 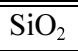 & $\overline{\mathrm{TiO}_{2}}$ & 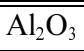 & $\mathrm{Cr}_{2} \mathrm{O}_{3}$ & $\overline{\mathrm{FeO}}$ & $\mathrm{MnO}$ & $\mathrm{MgO}$ & $\overline{\mathrm{CaO}}$ & $\mathrm{Na}_{2} \mathrm{O}$ & $\overline{\mathrm{K}} \mathrm{K}_{2} \mathrm{O}$ & " $\mathrm{NiO}$ & "Total & Fo \\
\hline \multirow{5}{*}{ Harzburgite } & SQ4-6 & 41.4 & 0 & 0.01 & 0.02 & 8.47 & 0.1 & 49.2 & 0 & 0 & 0 & 0.24 & 99.4 & 89.6 \\
\hline & SQ4-7 & 41.5 & 0.02 & 0 & 0.04 & 8.53 & 0.16 & 48.9 & 0.02 & 0 & 0.01 & 0.35 & 99.5 & 89.2 \\
\hline & SQ4-8 & 41.8 & 0.03 & 0.02 & 0.05 & 8.33 & 0.13 & 48.8 & 0 & 0 & 0 & 0.32 & 99.5 & 88.6 \\
\hline & SQ4-9 & 41.6 & 0.01 & 0.02 & 0.05 & 8.92 & 0.11 & 48.8 & 0.01 & 0.01 & 0 & 0.24 & 99.8 & 88.7 \\
\hline & SQ4-10 & 41.8 & 0.04 & 0 & 0.01 & 8.59 & 0.1 & 49.1 & 0.03 & 0 & 0 & 0.3 & 100 & 88.9 \\
\hline \multirow{5}{*}{ Mantle Dunite } & SQ5-6 & 40.6 & 0.01 & 0 & 0.03 & 8.41 & 0.13 & 49.9 & 0.08 & 0 & 0.01 & 0.44 & 99.6 & 91.9 \\
\hline & SQ5-7 & 40.9 & 0 & 0 & 0.19 & 8.39 & 0.08 & 50.1 & 0.05 & 0.02 & 0 & 0.39 & 100.1 & 91.7 \\
\hline & SQ5-8 & 41.1 & 0 & 0.01 & 0.11 & 8.41 & 0.11 & 49.8 & 0 & 0.01 & 0.01 & 0.37 & 99.9 & 91 \\
\hline & SQ5-9 & 41.1 & 0.02 & 0.01 & 0.09 & 8.43 & 0.08 & 49.9 & 0.02 & 0 & 0 & 0.42 & 100.1 & 91 \\
\hline & SQ5-10 & 40.8 & 0 & 0.01 & 0.04 & 8.48 & 0.09 & 50.2 & 0 & 0.01 & 0 & 0.43 & 100.1 & 91.9 \\
\hline \multirow{5}{*}{ MTZ Dunite } & HS4-6 & 40.6 & 0.01 & 0.01 & 0.01 & 10.3 & 0.18 & 48.4 & 0.05 & 0 & 0.02 & 0.43 & 100 & 89.5 \\
\hline & HS4-7 & 40.4 & 0 & 0.02 & 0 & 10.4 & 0.11 & 47.7 & 0.13 & 0 & 0 & 0.36 & 99.1 & 88.7 \\
\hline & HS4-8 & 40.5 & 0.03 & 0 & 0.03 & 10.4 & 0.13 & 48.5 & 0.11 & 0.03 & 0.01 & 0.44 & 100.2 & 89.8 \\
\hline & HS4-9 & 40.7 & 0.01 & 0.01 & 0.02 & 10.5 & 0.13 & 48.4 & 0.06 & 0.01 & 0 & 0.39 & 100.2 & 89.2 \\
\hline & HS4-10 & 40.6 & 0.02 & 0 & 0.02 & 10.3 & 0.14 & 48.6 & 0.1 & 0.01 & 0 & 0.44 & 100.2 & 89.7 \\
\hline \multirow{5}{*}{$\begin{array}{c}\text { MTZ } \\
\text { Chromitites }\end{array}$} & HS2-9 & 41.9 & 0.01 & 0.02 & 0.02 & 7.31 & 0.14 & 49.1 & 0.05 & 0.02 & 0 & 0.55 & 99.1 & 89.4 \\
\hline & HS2-10 & 41.6 & 0.01 & 0.02 & 0.05 & 9.91 & 0.08 & 48.7 & 0.02 & 0 & 0 & 0.45 & 100.8 & 88.4 \\
\hline & HS2-11 & 40.8 & 0 & 0.01 & 0.03 & 8.54 & 0.11 & 49.9 & 0.04 & 0.01 & 0.02 & 0.52 & 100 & 91.7 \\
\hline & HS2-12 & 40.3 & 0.02 & 0 & 0.05 & 9.22 & 0.14 & 49.5 & 0.05 & 0.04 & 0.02 & 0.55 & 99.9 & 91.8 \\
\hline & HS2-13 & 41.7 & 0 & 0.01 & 0.04 & 9.66 & 0.09 & 48.8 & 0.02 & 0 & 0 & 0.47 & 100.8 & 88.5 \\
\hline \multirow{5}{*}{$\begin{array}{c}\text { Mantle } \\
\text { Chromitites }\end{array}$} & SQ1-9 & 42.2 & 0 & 0.01 & 0.13 & 4.39 & 0.05 & 52.7 & 0.1 & 0 & 0 & 0.4 & 100 & 94.2 \\
\hline & SQ1-10 & 41.7 & 0 & 0 & 0.28 & 4.33 & 0.11 & 52.4 & 0.12 & 0.01 & 0.02 & 0.47 & 99.4 & 94.8 \\
\hline & SQ1-11 & 41.9 & 0.01 & 0.01 & 0.07 & 4.82 & 0.07 & 52.5 & 0.1 & 0 & 0.01 & 0.42 & 99.9 & 94.3 \\
\hline & SQ1-12 & 41.7 & 0.01 & 0 & 0.04 & 4.51 & 0.09 & 52.7 & 0.12 & 0.02 & 0.02 & 0.45 & 99.7 & 95.1 \\
\hline & SQ1-13 & 41.8 & 0.01 & 0.01 & 0.18 & 4.89 & 0.06 & 52.3 & 0.11 & 0 & 0 & 0.48 & 99.8 & 94.2 \\
\hline
\end{tabular}

Oxide values in weight percent, Fo (forsterite) or $\mathrm{Mg} \#=100 \times \mathrm{Mg} /\left(\mathrm{Mg}+\mathrm{Fe}^{2+}\right)$.

contents $(0.25$ to 0.64 wt $\%)$ and $\mathrm{Cr}_{2} \mathrm{O}_{3}(0.11$ to 0.49 wt $\%)$ with highest Mg\# values (97.6 to 99.3). Chromian spinel clinopyroxenes inclusions in high-Cr chromitites have the maximum $\mathrm{Cr}_{2} \mathrm{O}_{3}$ contents ranging from 1.13 to $1.22 \mathrm{wt} \%$. The clinopyroxene inclusions in spinels of high-Al chromitites are compared with those of high-Cr chromitites. These are having low $\mathrm{Mg \#} \mathrm{(96.5-97.0)} \mathrm{and} \mathrm{Cr}_{2} \mathrm{O}_{3}$ (0.41-0.44 wt \%) but have high $\mathrm{TiO}_{2}$ contents $(0.08$ to $0.09 \mathrm{wt} \%)$. The $\mathrm{Al}_{2} \mathrm{O}_{3}$ contents have positive correlation with $\mathrm{Cr}_{2} \mathrm{O}_{3}$ in all clinopyroxenes except for inclusions in the high-Cr chromitites chromian spinel (Fig. 6c).

Based on the composition of major elements all of orthopyroxenes fall in enstatite range (Fig. 6a). Those in the harzburgite and mantle dunite have almost comparable compositional characteristics of $\mathrm{Al}_{2} \mathrm{O}_{3}$ ( 0.16 to $0.59 \mathrm{wt} \%$ ), $\mathrm{Cr}_{2} \mathrm{O}_{3}$ ( 0.25 to $0.33 \mathrm{wt} \%$ ), and $\mathrm{Mg} \# \mathrm{~s}$ ( 90.4 to 91.3 ) as shown in Table 4, but those occurring as inclusions in high-Al spinel have higher $\mathrm{Cr}_{2} \mathrm{O}_{3}$ ranging from 0.56 to $0.58 \mathrm{wt} \%$ and $\mathrm{TiO}_{2}$ contents are about $0.05 \mathrm{wt} \%$ as compared to harzburgite and mantle dunite.

The amphiboles are mainly edenite or pargasite with high Mg\#s ranging from 91.7 to 93.3 (Fig. 6d). The $\mathrm{TiO}_{2}$ contents ( 0.29 to 0.64 wt $\%)$ in amphibole exhibit a negative correlation with $\mathrm{SiO}_{2}$ contents (44.5 to 47.2 wt\%) (Table 5; Fig. 6e).

\section{Geochemistry of Platinum Group Elements (PGEs)}

The total PGE concentrations in the harzburgite samples are rang- ing from 17.3 to $23.9 \mathrm{ppb}$ (Table 6), which are PGE depleted as compared to chondrite and there is a relatively flat pattern in about $0.01 \times$ chondrite (Fig. 7a). Mantle dunites samples have total PGE contents between 7.83 to $13.3 \mathrm{ppb}$ which are lower as compared to that harzburgite samples having Pt and Pd negative anomalies in the normalized PGE mood of chondrite values. The total PGE concentrations of the samples of MTZ dunite are lower (6.74 to $10.2 \mathrm{ppb}$ ) as compared to the total PGE concentrations of the mantle dunite which show flat PGE moods relative to the negative anomalies of Ir and Pt portion (Fig. 7a-b).

The concentrations of PGEs (112-258 ppb) of the high-Cr chromitites occurring in harzburgite and those of high-Al chromitites (39.1 to $200 \mathrm{ppb}$ ) found in the MTZ dunites are much higher than their host rocks, and also that of the primitive mantle (Table 6; Fig. 7a-b). The chondrite-normalized PGE patterns are steep in high-Cr chromitites which are enriched in the more refractory IPGE (iridium-group platinum group elements i.e., Os, Ir and Ru), comparative to the PPGE (palladium-group platinum group elements i.e., $\mathrm{Rh}, \mathrm{Pt}$ and $\mathrm{Pd}$ ) with negative anomalies of Ir and Pt. The high-Cr chromitites PPGE/IPGE proportions are 0.04 to 0.40 as shown in Table 6 . These high-Cr chromitites have lower $\mathrm{Pd} / \mathrm{Os}$ and $\mathrm{Pd} / \mathrm{Ir}$ values as compared to primitive mantle (Fig. 7c). Chondrite-normalized PGE pattern displaying positively sloping characteristics in high-Al chromitites (Fig. 7b) with relatively high ratios of PPGE/IPGE range from 0.60 to 6.24. These high-Al 


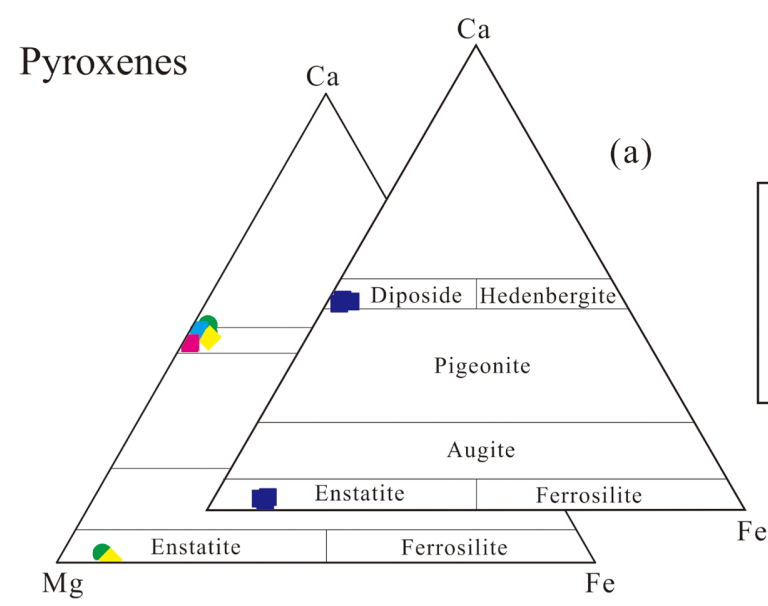

Harzburgite

Mantle Dunite

$\checkmark$ Interstitial in High-Cr Chromitites

Inclusion in chromian spinel High-Cr Chromitites

Inclusion in chromian spinel High-Al Chromitites
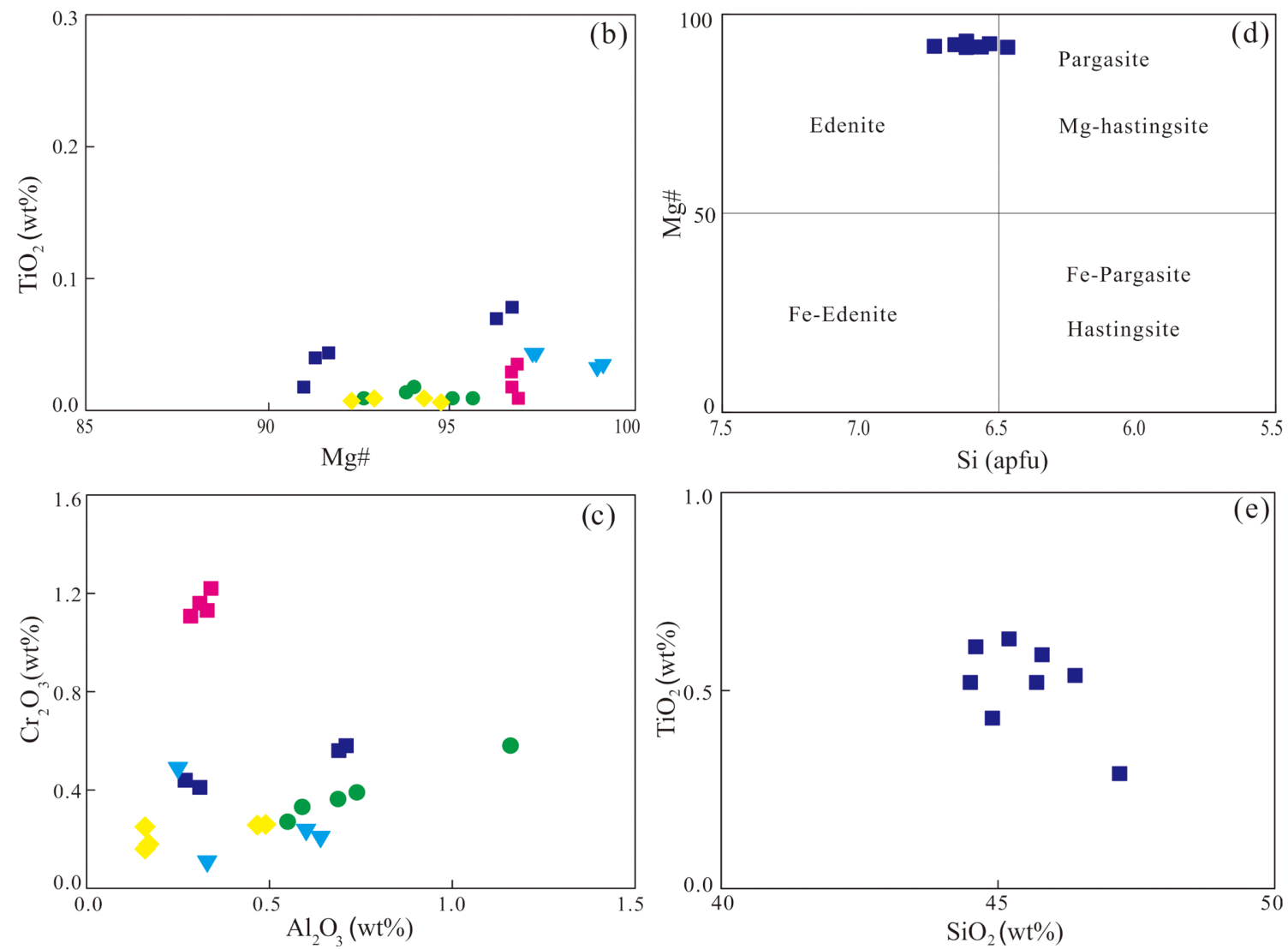

Figure 6. (a) Variation in Ca, Mg\# and Fe in the high-Cr and high-Al chromitites of Dargai Complex compared with host peridotites. All the clinopyroxenes are diopside and orthopyroxenes fall in enstatite range, (b) high-Cr and high-Al chromitites and peridotites TiO ${ }_{2}$ versus $\mathrm{Mg \# ,} \mathrm{(c)}$ $\mathrm{Cr}_{2} \mathrm{O}_{3}$ (wt\%) versus $\mathrm{Al}_{2} \mathrm{O}_{3}$ (wt\%), (d) $\mathrm{Mg}$ \# versus $\mathrm{Si}$ (atoms per formula unit) of high-Al chromitites amphiboles, (e) $\mathrm{TiO}_{2}$ (wt\%) versus $\mathrm{SiO}_{2}$ (wt $\%$ ).

chromitites also show increase in $\mathrm{Pd} / \mathrm{Os}$ values with increasing in the $\mathrm{Pd} / \mathrm{Ir}$ values, which plots on a different trend than the chromitites of high-Cr varieties (Fig. 7c).

\section{Discussion}

\section{Partial Melting Processes and Products}

Experimental work has demonstrated that the chemistry of chromite and olivine is strongly dependent on the composition of their parental magma (Dick and Bullen, 1984; Arai, 1992; Kamenetsky et al., 2001; Irvine, 2009; Page and Barnes, 2009; Zhou et al., 2014). It is commonly acknowledged that the chromitites parental melts are the product of melt-melt interactions or melt-rock reactions previously depleted in mantle sources in supra subduction zone environment (SSZ) (Zhou et al., 1994, 1998; Zhou and Robinson, 1997; Melcher et al., 1999; Kamenetsky et al., 2001; Uysal et al., 2005, 2009b). However, there is still a discussion on the genesis of different geochemical characteristics of chromitites with different melts in similar tectonic environments (e.g., high-Cr and high-Ti, high-Cr and low-Ti, and high-Al and high-Ti) (Rollinson, 2008; Arai et al., 2011; González-Jiménez et al., 2011; Pal, 
Table 4. Representative composition of pyroxenes in peridotites and chromitites of Dargai Complex through EPMA (wt\%)

\begin{tabular}{|c|c|c|c|c|c|c|c|c|c|c|c|c|c|c|c|c|c|c|}
\hline \multirow{3}{*}{$\begin{array}{l}\text { Lithology } \\
\text { Sample }\end{array}$} & \multicolumn{4}{|c|}{ Harzburgite } & \multicolumn{4}{|c|}{ Mantle Dunite } & \multicolumn{4}{|c|}{ "High-Al Chromitites } & \multicolumn{3}{|c|}{ "High-Cr Chromitites } & \multicolumn{3}{|c|}{ "High-Cr Chromitites } \\
\hline & \multicolumn{4}{|c|}{ matrix minerals } & \multicolumn{4}{|c|}{ matrix minerals } & \multicolumn{4}{|c|}{ inclusions in chromian spinel } & \multicolumn{3}{|c|}{ matrix minerals } & \multicolumn{3}{|c|}{ inclusions in chromian spinel } \\
\hline & ${ }^{*} \mathrm{Cpx}$ & $\mathrm{Cpx}$ & $* * \mathrm{Opx}$ & Opx & Cpx & Cpx & Opx & Opx & Opx & Opx & Cpx & Cpx & Cpx & Cpx & $\mathrm{Cpx}$ & $\mathrm{Cpx}$ & $\mathrm{Cpx}$ & $\mathrm{Cpx}$ \\
\hline $\mathrm{SiO}_{2}$ & 54.3 & 54.1 & 56.8 & 57.2 & 53.9 & 54.6 & 56.2 & 56.1 & 57.2 & 56.8 & 54.1 & 54.5 & 55.2 & 54.9 & 54.5 & 54.8 & 54.7 & 54.6 \\
\hline $\mathrm{TiO}_{2}$ & 0.01 & 0.01 & 0.02 & 0.01 & 0 & 0.01 & 0 & 0.01 & 0.02 & 0.05 & 0.09 & 0.08 & 0.05 & 0.05 & 0.04 & 0.01 & 0.02 & 0.04 \\
\hline $\mathrm{Al}_{2} \mathrm{O}_{3}$ & 0.74 & 1.16 & 0.59 & 0.55 & 0.16 & 0.17 & 0.49 & 0.16 & 0.69 & 0.71 & 0.27 & 0.31 & 0.64 & 0.25 & 0.33 & 0.31 & 0.33 & 0.34 \\
\hline $\mathrm{Cr}_{2} \mathrm{O}_{3}$ & 0.39 & 0.58 & 0.33 & 0.27 & 0.16 & 0.18 & 0.26 & 0.25 & 0.56 & 0.58 & 0.44 & 0.41 & 0.21 & 0.49 & 0.11 & 1.16 & 1.13 & 1.22 \\
\hline $\mathrm{FeO}$ & 1.58 & 1.65 & 6.13 & 6.16 & 1.97 & 1.91 & 6.66 & 6.62 & 6.69 & 6.73 & 1.42 & 1.13 & 0.73 & 0.77 & 0.99 & 0.96 & 1.04 & 0.97 \\
\hline $\mathrm{MnO}$ & 0.09 & 0.05 & 0.14 & 0.15 & 0.08 & 0.07 & 0.13 & 0.12 & 0.13 & 0.12 & 0.06 & 0.06 & 0.04 & 0.02 & 0.04 & 0.07 & 0.06 & 0.07 \\
\hline $\mathrm{MgO}$ & 17.2 & 17.4 & 35.2 & 34.9 & 17.3 & 17.4 & 34.3 & 34.5 & 34.3 & 34.4 & 17.5 & 17.4 & 17.7 & 17.8 & 18.1 & 18.6 & 18.7 & 18.5 \\
\hline $\mathrm{CaO}$ & 24.7 & 24.9 & 0.68 & 0.63 & 24.5 & 24.3 & 0.33 & 0.35 & 0.41 & 0.47 & 25.2 & 24.9 & 24.6 & 25.2 & 25.3 & 23.3 & 23.4 & 23.4 \\
\hline $\mathrm{Na}_{2} \mathrm{O}$ & 0.08 & 0.07 & 0.02 & 0.01 & 0.08 & 0.09 & 0.02 & 0.02 & 0.02 & 0.01 & 0.05 & 0.01 & 0.33 & 0.19 & 0.05 & 0.15 & 0.19 & 0.15 \\
\hline $\mathrm{K}_{2} \mathrm{O}$ & 0.01 & 0.01 & 0 & 0 & 0.02 & 0.02 & 0.01 & 0.01 & 0.01 & 0 & 0.01 & 0.01 & 0.01 & 0 & 0.01 & 0.01 & 0 & 0.01 \\
\hline $\mathrm{NiO}$ & 0.06 & 0.05 & 0.08 & 0.06 & 0.06 & 0.05 & 0.14 & 0.13 & 0.08 & 0.11 & 0.05 & 0.04 & 0.07 & 0.08 & 0.08 & 0.09 & 0.11 & 0.07 \\
\hline Total & 99.2 & 100 & 100 & 99.9 & 98.2 & 98.8 & 98.5 & 98.3 & 100 & 100 & 99.2 & 98.9 & 99.6 & 99.8 & 99.6 & 99.5 & 99.7 & 99.4 \\
\hline \multicolumn{19}{|c|}{$\mathrm{O}=6$} \\
\hline $\mathrm{Si}$ & 1.990 & 1.965 & 1.954 & 1.971 & 1.994 & 2.008 & 1.968 & 1.969 & 1.976 & 1.964 & 1.980 & 2.002 & 2.004 & 1.993 & 1.981 & 1.994 & 1.985 & 1.989 \\
\hline $\mathrm{Ti}$ & 0.000 & 0.000 & 0.001 & 0.000 & 0.000 & 0.000 & 0.000 & 0.000 & 0.001 & 0.001 & 0.002 & 0.002 & 0.001 & 0.001 & 0.001 & 0.000 & 0.001 & 0.001 \\
\hline $\mathrm{Al}$ & 0.032 & 0.050 & 0.024 & 0.022 & 0.007 & 0.007 & 0.020 & 0.007 & 0.028 & 0.029 & 0.012 & 0.013 & 0.027 & 0.011 & 0.014 & 0.013 & 0.014 & 0.015 \\
\hline $\mathrm{Cr}$ & 0.011 & 0.017 & 0.009 & 0.007 & 0.005 & 0.005 & 0.007 & 0.007 & 0.015 & 0.016 & 0.013 & 0.012 & 0.006 & 0.014 & 0.003 & 0.033 & 0.032 & 0.035 \\
\hline $\mathrm{Fe}^{3+}$ & 0.000 & 0.008 & 0.059 & 0.028 & 0.008 & 0.000 & 0.038 & 0.051 & 0.006 & 0.025 & 0.014 & 0.000 & 0.000 & 0.000 & 0.023 & 0.000 & 0.000 & 0.000 \\
\hline $\mathrm{Mn}$ & 0.003 & 0.002 & 0.004 & 0.004 & 0.003 & 0.002 & 0.004 & 0.004 & 0.004 & 0.004 & 0.002 & 0.002 & 0.001 & 0.001 & 0.001 & 0.002 & 0.002 & 0.002 \\
\hline $\mathrm{Mg}$ & 0.940 & 0.942 & 1.806 & 1.793 & 0.954 & 0.954 & 1.791 & 1.805 & 1.766 & 1.773 & 0.955 & 0.953 & 0.958 & 0.963 & 0.981 & 1.009 & 1.012 & 1.005 \\
\hline $\mathrm{Ca}$ & 0.970 & 0.969 & 0.025 & 0.023 & 0.971 & 0.957 & 0.012 & 0.013 & 0.015 & 0.017 & 0.988 & 0.980 & 0.957 & 0.980 & 0.985 & 0.908 & 0.910 & 0.913 \\
\hline $\mathrm{Fe}^{2+}$ & 0.048 & 0.042 & 0.117 & 0.149 & 0.053 & 0.059 & 0.158 & 0.144 & 0.187 & 0.170 & 0.030 & 0.035 & 0.022 & 0.023 & 0.007 & 0.029 & 0.032 & 0.030 \\
\hline $\mathrm{Na}$ & 0.006 & 0.005 & 0.001 & 0.001 & 0.006 & 0.006 & 0.001 & 0.001 & 0.001 & 0.001 & 0.004 & 0.001 & 0.023 & 0.013 & 0.004 & 0.011 & 0.013 & 0.011 \\
\hline $\mathrm{K}$ & 0.000 & 0.000 & 0.000 & 0.000 & 0.001 & 0.001 & 0.000 & 0.000 & 0.000 & 0.000 & 0.000 & 0.000 & 0.000 & 0.000 & 0.000 & 0.000 & 0.000 & 0.000 \\
\hline $\mathrm{Ni}$ & 0.002 & 0.001 & 0.002 & 0.002 & 0.002 & 0.001 & 0.004 & 0.004 & 0.002 & 0.003 & 0.001 & 0.001 & 0.002 & 0.002 & 0.002 & 0.003 & 0.003 & 0.002 \\
\hline $\mathrm{Mg} \#$ & 95.1 & 95.7 & 93.9 & 92.3 & 94.7 & 94.2 & 91.9 & 92.6 & 90.4 & 91.3 & 97.0 & 96.5 & 97.7 & 97.6 & 99.3 & 97.2 & 97.0 & 97.1 \\
\hline
\end{tabular}

Oxide values in weight percent, chemical formulae calculated on the basis of 6 oxygens, ${ }^{*} \mathrm{Cpx}=$ Clinopyroxene; $* *$ Opx $=$ Orthopyroxene; Mg\# $=100$ $\times \mathrm{Mg} /\left(\mathrm{Mg}+\mathrm{Fe}^{2+}\right)$.

2011; Zaccarini et al., 2011). In various types of melts, the total concentration of $\mathrm{Cr}_{2} \mathrm{O}_{3}$ and $\mathrm{Al}_{2} \mathrm{O}_{3}$ is controlling the $\mathrm{Cr} / \mathrm{Al}$ ratio of chromian spinel, although these two elements have negative correlation to each other. The concentrations of $\mathrm{Al}$ and $\mathrm{Ti}$ in chromian spinel are directly transferred from their parent magma and can be used to restrain the primary melt composition, thus providing a basis for further understanding of tectonic background of podiform chromitites and the host ophiolites (Barnes and Roeder, 2001; Kamenetsky et al., 2001; Page and Barnes, 2009; Uysal et al., 2009a; Gonzalez-Jimenez et al., 2011; Zaccarini et al., 2011; Rollinson and Adetunji, 2013).

Kamenetsky et al. (2001) presented that there is a linear relationship between the $\mathrm{TiO}_{2}$ and $\mathrm{Al}_{2} \mathrm{O}_{3}$ contents of chromian spinel and the melt from which it crystallized by using parental melt in chromian spinel from volcanic rocks. Following the method of Rollinson (2008) (for arc sequences acquired from Kamenetsky et al., 2001), the $\mathrm{Al}_{2} \mathrm{O}_{3}$ and $\mathrm{TiO}_{2}$ contents of parental melts are in equilibrium with the chromitites samples. The $\mathrm{Al}_{2} \mathrm{O}_{3}$ and $\mathrm{TiO}_{2}$ contents of the magmas from which the Sakhakot-Qila high-Cr chromitites have been crystallized are determined by using the equations proposed by Rollinson (2008) and Rollinson and Adetunji (2015);

$$
\begin{aligned}
& \mathrm{Al}_{2} \mathrm{O}_{3}-\text { melt }=7.1518 \times \mathrm{Al}_{2} \mathrm{O}_{3}-\text { spinel }^{0.2387} \\
& \mathrm{TiO}_{2}-\text { melt }=1.5907 \times \mathrm{TiO}_{2}-\text { spinel }^{0.6322}
\end{aligned}
$$

To conclude $\mathrm{Al}_{2} \mathrm{O}_{3}$ and $\mathrm{TiO}_{2}$ contents of magmas due to which the Heru-Shah high-Al chromitites precipitated the following equations are used for MOR settings;

$$
\begin{aligned}
& \mathrm{Al}_{2} \mathrm{O}_{3}-\text { melt }=5.2181 \times \ln \left(\mathrm{Al}_{2} \mathrm{O}_{3}-\text { spinel }\right)-1.0505 \\
& \mathrm{TiO}_{2}-\text { melt }=1.0963 \times \mathrm{TiO}_{2}-\text { spinel }^{0.7863}
\end{aligned}
$$

Based on calculations, the high-Cr chromitites precipitated from magmas with $\mathrm{Al}_{2} \mathrm{O}_{3 \text { (melt) }}$ ranging from 10.2 to $11.2 \mathrm{wt} \%$ and $\mathrm{TiO}_{2 \text { (melt) }}$ contents ranging from 0.12 to $0.30 \mathrm{wt} \%$, correspondingly (Fig. 8a-b). The values that are similar to those of high-Cr chromitites parental melts in the Bonin Island, Japan (Hickey and Frey, 1982), Semail Ophiolite, Oman (Rollinson, 2008), the Therford Mines Ophiolite, Canada (Page and Barnes, 2009), the Sagua de Tanamo Ophiolite, Eastern Cuba (Gonzalez-Jimenez et al., 2011) and the Harmancik and Kizilyuksek Ophiolite, Turkey (Uysal et al., 2015; Avc1 et al., 2017). In these regions the high-Cr chromitites are supposed to have formed in the subduction zone environments from boninitic melts similar to that of 
Table 5. Representative composition of amphibole inclusions in chromian spinel of the high-Al chromitites in the mantle-crust transition zone (MTZ) dunites of Dargai Complex through EPMA (wt\%)

\begin{tabular}{|c|c|c|c|c|c|c|c|c|}
\hline "Sample No & "HS2-a3 & HS2-a5 & "HS2-a6 & HS2-a7 & HS2-a9 & HS2-a11 & HS2-a14 & "HS2-a15 \\
\hline $\mathrm{SiO}_{2}$ & 45.7 & 47.2 & 46.4 & 45.8 & 45.2 & 44.6 & 44.9 & 44.5 \\
\hline $\mathrm{TiO}_{2}$ & 0.52 & 0.29 & 0.64 & 0.59 & 0.63 & 0.61 & 0.43 & 0.52 \\
\hline $\mathrm{Al}_{2} \mathrm{O}_{3}$ & 9.65 & 8.91 & 9.39 & 9.02 & 8.99 & 9.01 & 9.01 & 8.41 \\
\hline $\mathrm{Cr}_{2} \mathrm{O}_{3}$ & 2.57 & 1.93 & 2.13 & 2.51 & 2.09 & 2.16 & 2.05 & 1.99 \\
\hline $\mathrm{FeO}$ & 3.14 & 2.96 & 3.13 & 3.11 & 2.51 & 2.77 & 2.46 & 2.78 \\
\hline $\mathrm{MnO}$ & 0.08 & 0.06 & 0.04 & 0.07 & 0.05 & 0.04 & 0.07 & 0.05 \\
\hline $\mathrm{MgO}$ & 19.4 & 18.9 & 19.3 & 19.5 & 19.2 & 19.4 & 19.1 & 18.8 \\
\hline $\mathrm{CaO}$ & 13.2 & 12.4 & 12.4 & 12.3 & 12.7 & 12.5 & 12.2 & 12.3 \\
\hline $\mathrm{Na}_{2} \mathrm{O}$ & 4.36 & 4.11 & 3.09 & 2.51 & 2.77 & 2.49 & 2.18 & 2.15 \\
\hline $\mathrm{K}_{2} \mathrm{O}$ & 0.21 & 0.44 & 0.25 & 0.19 & 0.37 & 0.22 & 0.34 & 0.25 \\
\hline $\mathrm{NiO}$ & 0.11 & 0.14 & 0.11 & 0.15 & 0.12 & 0.11 & 0.18 & 0.14 \\
\hline Total & 99.9 & 99.3 & 99.9 & 99.8 & 99.6 & 99.9 & 99.9 & 99.9 \\
\hline \multicolumn{9}{|c|}{$\mathrm{O}=23$} \\
\hline $\mathrm{Si}$ & 6.469 & 6.733 & 6.618 & 6.564 & 6.617 & 6.533 & 6.618 & 6.658 \\
\hline $\mathrm{Ti}$ & 0.055 & 0.031 & 0.069 & 0.064 & 0.069 & 0.067 & 0.048 & 0.059 \\
\hline $\mathrm{Al}$ & 1.61 & 1.498 & 1.578 & 1.523 & 1.551 & 1.555 & 1.565 & 1.483 \\
\hline $\mathrm{Cr}$ & 0.288 & 0.218 & 0.24 & 0.284 & 0.242 & 0.25 & 0.239 & 0.235 \\
\hline $\mathrm{Mn}$ & 0.01 & 0.007 & 0.005 & 0.008 & 0.006 & 0.005 & 0.009 & 0.006 \\
\hline $\mathrm{Mg}$ & 4.094 & 4.019 & 4.104 & 4.166 & 4.19 & 4.237 & 4.197 & 4.194 \\
\hline $\mathrm{Ca}$ & 2.002 & 1.895 & 1.895 & 1.888 & 1.992 & 1.962 & 1.926 & 1.972 \\
\hline $\mathrm{Na}$ & 1.196 & 1.137 & 0.854 & 0.697 & 0.786 & 0.707 & 0.623 & 0.624 \\
\hline $\mathrm{K}$ & 0.038 & 0.08 & 0.045 & 0.035 & 0.069 & 0.041 & 0.064 & 0.048 \\
\hline $\mathrm{Ni}$ & 0.013 & 0.016 & 0.013 & 0.017 & 0.014 & 0.013 & 0.021 & 0.017 \\
\hline $\mathrm{Fe}^{(\mathrm{iii})}$ & 0 & 0 & 0 & 0 & 0 & 0 & 0 & 0 \\
\hline $\mathrm{Fe}^{(\mathrm{ii})}$ & 0.372 & 0.353 & 0.373 & 0.373 & 0.307 & 0.339 & 0.303 & 0.348 \\
\hline $\mathrm{Al}^{(\mathrm{IV})}$ & 1.531 & 1.267 & 1.382 & 1.436 & 1.383 & 1.467 & 1.382 & 1.342 \\
\hline $\mathrm{Al}^{(\mathrm{VI})}$ & 0.078 & 0.231 & 0.196 & 0.087 & 0.168 & 0.089 & 0.183 & 0.141 \\
\hline $\mathrm{Ca}^{(\mathrm{C})}$ & 0.104 & 0.141 & 0.013 & 0.017 & 0.017 & 0.013 & 0.021 & 0.017 \\
\hline $\left.\mathrm{Ca}^{(\mathrm{B}}\right)$ & 1.898 & 1.754 & 1.882 & 1.871 & 1.975 & 1.949 & 1.905 & 1.955 \\
\hline $\mathrm{Na}^{(\mathrm{B})}$ & 0.102 & 0.246 & 0.118 & 0.129 & 0.025 & 0.051 & 0.095 & 0.045 \\
\hline $\mathrm{Na}^{(\mathrm{A})}$ & 1.094 & 0.891 & 0.737 & 0.569 & 0.761 & 0.656 & 0.528 & 0.579 \\
\hline $\mathrm{K}^{(\mathrm{A})}$ & 0.038 & 0.08 & 0.045 & 0.035 & 0.069 & 0.041 & 0.064 & 0.048 \\
\hline Mg\# & 91.7 & 91.9 & 91.7 & 91.8 & 93.2 & 92.6 & 93.3 & 92.3 \\
\hline
\end{tabular}

Oxide values in weight percent, chemical formulae calculated on the basis of 23 oxygens, $\mathrm{Mg} \#=100 \times \mathrm{Mg} /\left(\mathrm{Mg}+\mathrm{Fe}^{2+}\right)$.

the Sakhakot-Qila chromitites (Ahmed, 1982, 1984).

The $\mathrm{Al}_{2} \mathrm{O}_{3}$ and $\mathrm{TiO}_{2}$ contents of the parental magma of the high-Al chromitites are normally ranging from 15.1 to $15.8 \mathrm{wt} \%$ and 0.44 to $0.71 \mathrm{wt} \%$, respectively. The $\mathrm{Al}_{2} \mathrm{O}_{3}$ contents $(16 \mathrm{wt} \%$, Fig. $8 \mathrm{a}$ ) of the studied high-Al chromitites samples are in good match with those of MORB environment (Wilson, 1989). This indicates their precipitation in a MORB type environment. However, the parental magmas of chromitites of high-Al are not of typical mid oceanic ridges basaltic magmas because they have lower $\mathrm{TiO}_{2}$ than the normal concentrations (Fig. 8b). This suggests that, the magma is likely to have undergone low degree of melt extraction through a partial melting of residual mantle.

\section{Oxygen Fugacity $\left(\mathrm{fO}_{2}\right)$ of Chromitite and Peridotite}

Oxygen fugacity $\left(\mathrm{fO}_{2}\right)$ of the earth's mantle is one of the intensive variables restraining the progression of mantle derived magmatic rocks. The $\mathrm{fO}_{2}$ of podiform chromitites and associated ultramafic rocks contributes the direct evidence of the deep physical and chemical phenomenon occurred in the earth's mantle (Ballhaus et al., 1991). In the other tectonic settings, it is found that the mantle wedge above the subduction zone setting is more oxidized than the mantle (Ballhaus et al., 1991; Parkinson and Arculus, 1999). The oxygen fugacity of high-Cr chromitites, mantle dunites and harzburgites has been calculated on the basis of microprobe analysis of the studied olivine and chromian spinel pairs according to Ballhaus et al. (1991) and Sack and Ghiosro (1991). The $\mathrm{fO}_{2}$ contents of high-Al chromitites and MTZ dunites have also been considered for comparisons. On the basis of average mineral chemistry, the $\mathrm{fO}_{2}$ contents have been calculated and the results are shown in Table 7 as deviation $\left(\Delta \operatorname{logfO} \mathrm{O}_{2} \mathrm{FMQ}\right)$ from the fayalite-magnetite-quartz (FMQ) buffer at $1.0 \mathrm{GPa}$. The $\mathrm{fO}_{2}$ values 
Table 6. Platinum group element compositions of whole rock samples of the chromitites and peridotites in the Dargai Complex

\begin{tabular}{|c|c|c|c|c|c|c|c|c|c|c|c|c|c|}
\hline Lithology & P.No & Os & Ir & $\overline{\mathrm{Ru}}$ & Rh & $\overline{\mathrm{Pt}}$ & $\overline{P d}$ & 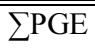 & $\mathrm{Pd} / \mathrm{Ir}$ & OS/Ir & $\mathrm{Pd} / \mathrm{Os}$ & $\overline{\mathrm{Ir} /(\mathrm{Pt}+\mathrm{Pd})}$ & 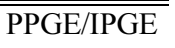 \\
\hline \multirow{8}{*}{$\begin{array}{l}\text { High-Cr } \\
\text { Chromitites }\end{array}$} & SQ3 & 33.5 & 14.8 & 43.6 & 3.39 & 17.2 & 12.8 & 125.3 & 0.86 & 2.38 & 0.36 & 0.49 & 0.37 \\
\hline & SQ9 & 49.2 & 39.3 & 38.3 & 7.06 & 3.19 & 0.48 & 137.5 & 0.02 & 1.60 & 0.01 & 10.7 & 0.04 \\
\hline & SQ10 & 45.3 & 12.7 & 98.1 & 2.77 & 13.6 & 4.99 & 177.5 & 0.50 & 4.56 & 0.11 & 0.68 & 0.06 \\
\hline & SQ12 & 72.4 & 47.6 & 92.7 & 1.83 & 2.36 & 41.6 & 258.5 & 1.11 & 1.94 & 0.57 & 1.08 & 0.12 \\
\hline & SQ14 & 87.8 & 16.5 & 22.8 & 5.45 & 0.95 & 19.4 & 152.9 & 1.49 & 6.80 & 0.22 & 0.81 & 0.14 \\
\hline & SQ16 & 38.7 & 11.1 & 71.3 & 10.5 & 8.38 & 2.07 & 142.1 & 0.24 & 4.45 & 0.05 & 1.06 & 0.07 \\
\hline & SQ19 & 35.9 & 32.2 & 29.2 & 6.91 & 6.13 & 1.92 & 112.3 & 0.08 & 1.42 & 0.05 & 4.00 & 0.08 \\
\hline & SQ20 & 42.4 & 44.7 & 36.9 & 5.71 & 1.47 & 9.18 & 140.4 & 0.26 & 1.21 & 0.21 & 4.20 & 0.08 \\
\hline \multirow{8}{*}{$\begin{array}{l}\text { High-Al } \\
\text { Chromitites }\end{array}$} & HS1 & 7.98 & 2.47 & 22.6 & 1.58 & 14.9 & 53.9 & 103.4 & 27.6 & 4.13 & 6.69 & 0.04 & 0.97 \\
\hline & HS7 & 9.15 & 1.84 & 16.8 & 9.97 & 52.2 & 23.1 & 113.1 & 15.9 & 6.35 & 2.50 & 0.02 & 1.43 \\
\hline & HS9 & 3.01 & 5.26 & 7.12 & 2.94 & 39.4 & 125 & 182.7 & 30.1 & 0.73 & 41.1 & 0.03 & 6.24 \\
\hline & HS10 & 9.91 & 4.39 & 5.55 & 1.79 & 5.52 & 11.9 & 39.1 & 3.43 & 2.88 & 1.19 & 0.25 & 0.64 \\
\hline & HS11 & 2.96 & 7.09 & 11.7 & 2.13 & 18.8 & 91.2 & 133.9 & 16.3 & 0.53 & 30.5 & 0.06 & 2.75 \\
\hline & HS12 & 7.11 & 2.17 & 28.9 & 1.43 & 89.2 & 71.4 & 200.2 & 41.7 & 4.19 & 9.95 & 0.01 & 1.84 \\
\hline & HS13 & 6.35 & 7.98 & 14.2 & 7.36 & 4.44 & 25.8 & 66.1 & 4.09 & 1.02 & 4.03 & 0.26 & 0.66 \\
\hline & HS14 & 4.51 & 1.88 & 25.4 & 2.04 & 8.16 & 64.1 & 106.1 & 43.2 & 3.07 & 14.1 & 0.03 & 0.97 \\
\hline \multirow{4}{*}{ Harzburgite } & SQ6 & 4.19 & 3.08 & 5.98 & 1.21 & 4.79 & 4.53 & 23.8 & 1.86 & 1.74 & 1.07 & 0.33 & 0.43 \\
\hline & SQ8 & 5.31 & 2.54 & 6.58 & 0.84 & 5.67 & 2.99 & 23.9 & 1.49 & 2.67 & 0.56 & 0.29 & 0.36 \\
\hline & SQ11 & 4.87 & 2.93 & 3.87 & 0.92 & 4.63 & 0.41 & 17.6 & 0.18 & 2.12 & 0.08 & 0.58 & 0.31 \\
\hline & SQ15 & 3.75 & 3.38 & 6.12 & 0.75 & 5.85 & 1.46 & 21.3 & 0.55 & 1.42 & 0.39 & 0.46 & 0.33 \\
\hline \multirow{4}{*}{ Mantle Dunites } & SQ7 & 3.22 & 1.21 & 4.11 & 0.31 & 1.12 & 2.97 & 12.9 & 3.11 & 3.40 & 0.91 & 0.30 & 0.28 \\
\hline & SQ13 & 0.78 & 2.89 & 2.75 & 0.55 & 0.55 & 0.31 & 7.83 & 0.14 & 0.34 & 0.39 & 3.36 & 0.11 \\
\hline & SQ17 & 3.49 & 1.09 & 1.01 & 0.44 & 2.19 & 0.59 & 8.81 & 0.69 & 4.09 & 0.17 & 0.39 & 0.42 \\
\hline & SQ17 & 2.83 & 0.84 & 5.81 & 0.38 & 1.85 & 1.63 & 13.3 & 2.46 & 4.30 & 0.57 & 0.24 & 0.19 \\
\hline \multirow{4}{*}{ MTZ Dunites } & HS4 & 0.74 & 0.37 & 2.03 & 0.21 & 2.34 & 1.05 & 6.74 & 3.59 & 2.56 & 1.41 & 0.11 & 0.53 \\
\hline & HS5 & 0.99 & 1.22 & 1.11 & 0.91 & 0.53 & 2.53 & 7.29 & 2.63 & 1.04 & 2.53 & 0.40 & 0.71 \\
\hline & HS6 & 2.33 & 0.78 & 4.52 & 0.18 & 1.67 & 0.75 & 10.2 & 1.22 & 3.82 & 0.32 & 0.32 & 0.16 \\
\hline & HS8 & 1.65 & 0.93 & 1.58 & 0.15 & 3.79 & 1.93 & 10.0 & 2.63 & 2.27 & 1.16 & 0.16 & 0.87 \\
\hline *PM & & 514 & 540 & 690 & 200 & 1020 & 545 & & & & & & \\
\hline$* * \mathrm{CC} 1$ & & 3.40 & 3.20 & 2.00 & 0.90 & 7.10 & 3.90 & & & & & & \\
\hline
\end{tabular}

Contents are in ppm, IPGE $=\mathrm{Ir}, \mathrm{Os}, \mathrm{Ru}, \mathrm{PPGE}=\mathrm{Pd}, \mathrm{Pt}, \mathrm{Rh}, * \mathrm{PM}$ (primitive mantle) values used from McDonough and sun (1995); **CC1 (chondrite of average type C1) values used from Naldrett and Duke (1980).

obtained from the Sakhakot-Qila high-Cr chromitites (log units ranging from 0.83 to 1.85$)$, mantle dunite ( -0.04 to 1.26 ) and harzburgite (-1.76 to 0.21$)$ are higher or less than the FMQ buffer (Fig. 9). The high-Cr chromitites and mantle dunites chromian spinel have higher $\mathrm{Cr} \#$ values and oxygen fugacity with respect to associated harzburgite, which is thought to be due to interface between residual mantle harzburgite and boninitic melt in a supra-subduction zone (SSZ) setting (Ishii et al., 1992; Parkinson and Pearce, 1998).

The oxygen fugacity values of the Heru-Shah high-Al chromitites and mantle-crust transition zone (MTZ) dunites are higher than the fayalite-magnetite-quartz buffer, having log units for high-Al chromitites ranging from 0.43 to 1.53 and for MTZ dunites ranging from 1.09 to 1.98 (Table 7; Fig. 9). For MORB, these values have high oxygen fugacity than expected which is supposed to approximate the curve of FMQ (Cottrell and Kelley, 2011), but equivalent to those for high-Cr chromitites, mantle dunites and harzburgites which originated under supra-subduction zone setting. In addition, the occurrence of amphibole inclusions in the high-Al chromitites infers that they are precipi- tated by parental melts with hydrous nature. Therefore, the parent melts of high-Al chromitites are considered to be oxidized, hydrous in nature and poor in $\mathrm{TiO}_{2}$ but $\mathrm{Al}_{2} \mathrm{O}_{3}$ rich in characteristics.

\section{PGE Occurrences and Potential in Dargai Complex Chromitites and Peridotites}

In igneous rocks, the three main factors that usually control the PGE concentrations are the magmatic fractionation, partial melting and hydrothermal alteration processes (Barnes et al., 1985). The first two processes seem to be more effective while the last one have minor effect on the redistribution and remobilization to a slighter extent Pt and Pd. On the basis of compatibility of their melting temperature, PGEs are divided into two groups: the Ir-group, more refractory elements (IPGEs = $\mathrm{Os}$, Ir and $\mathrm{Ru}$ ) that have melting points $>2000{ }^{\circ} \mathrm{C}$, and the Pd-group, less refractory elements (PPGEs $=\mathrm{Rh}, \mathrm{Pt}, \mathrm{Pd})$ with melting points $<$ $2000^{\circ} \mathrm{C}$ (Barnes et al., 1985; Bockrath et al., 2004). The combined processes of partial melting and melt/rock interaction produced PGEs 


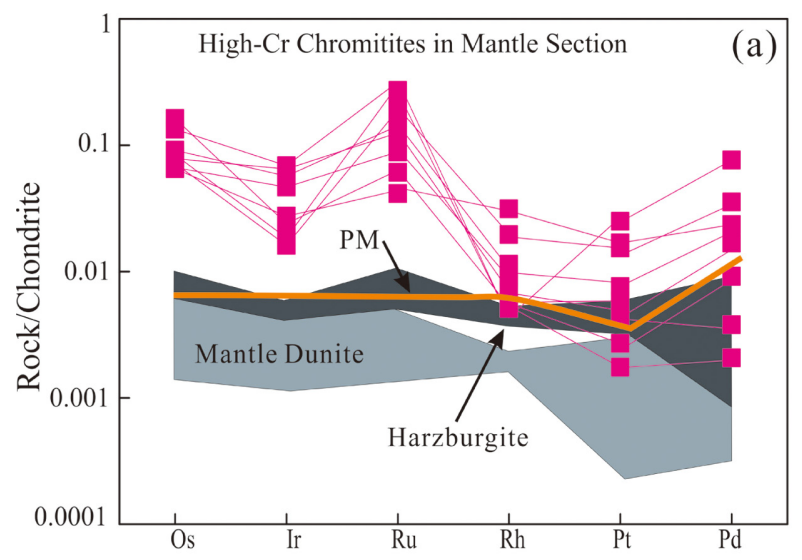

High-Cr Chromitites in mantle section

High-Al Chromitites in MTZ Dunite

Harzburgite

Mantle Dunite

MTZ Dunite
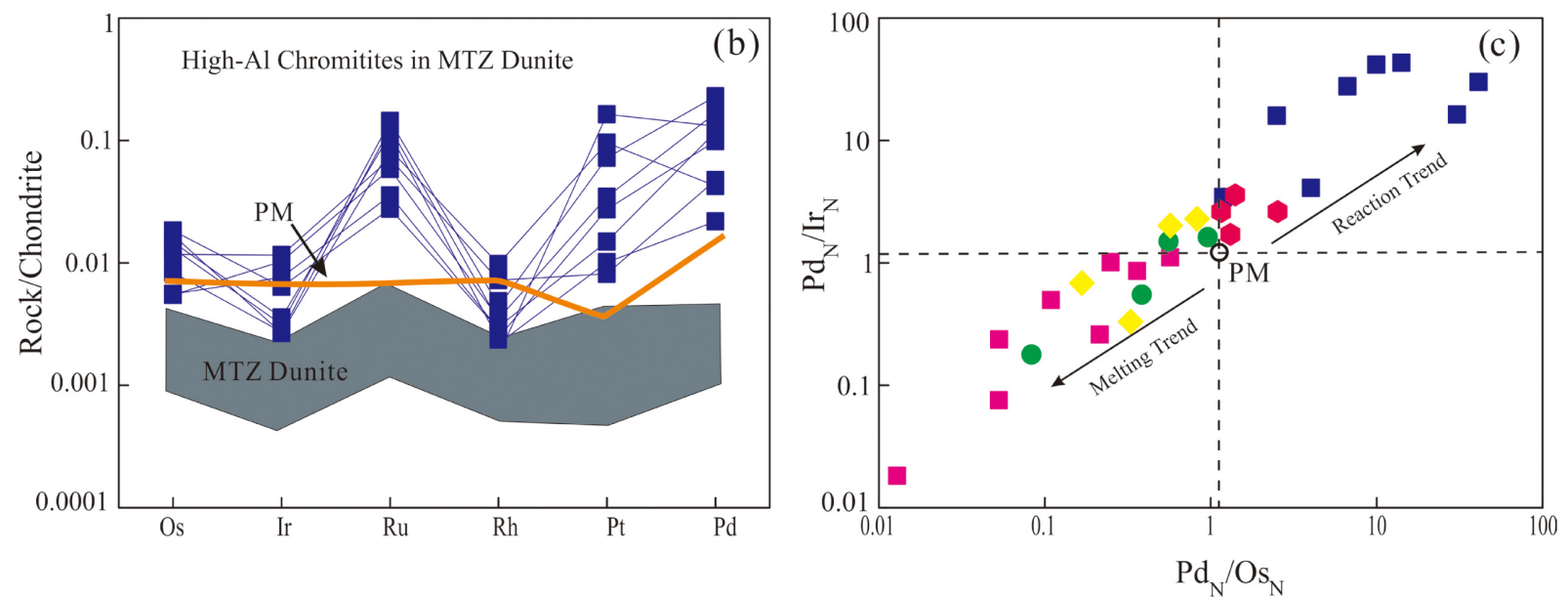

Figure 7. (a) Chondrite-normalized platinum group elements (PGE) patterns for the representative mantle dunites, harzburgite and high-Cr chromitites; (b) Chondrite-normalized platinum group elements patterns for the MTZ dunites and high-Al chromitites, (c) Chondrite-normalized $\mathrm{Pd}_{N} / \mathrm{Ir}_{N}$ versus $\mathrm{Pd}_{N} / O \mathrm{~s}_{N}$ for the peridotites and high-Cr and high-Al chromitites. Platinum group elements (PGE) values of the PM (primitive mantle) are from McDonough and Sun (1995), and chondrite values are from Naldrett and Duke (1980).
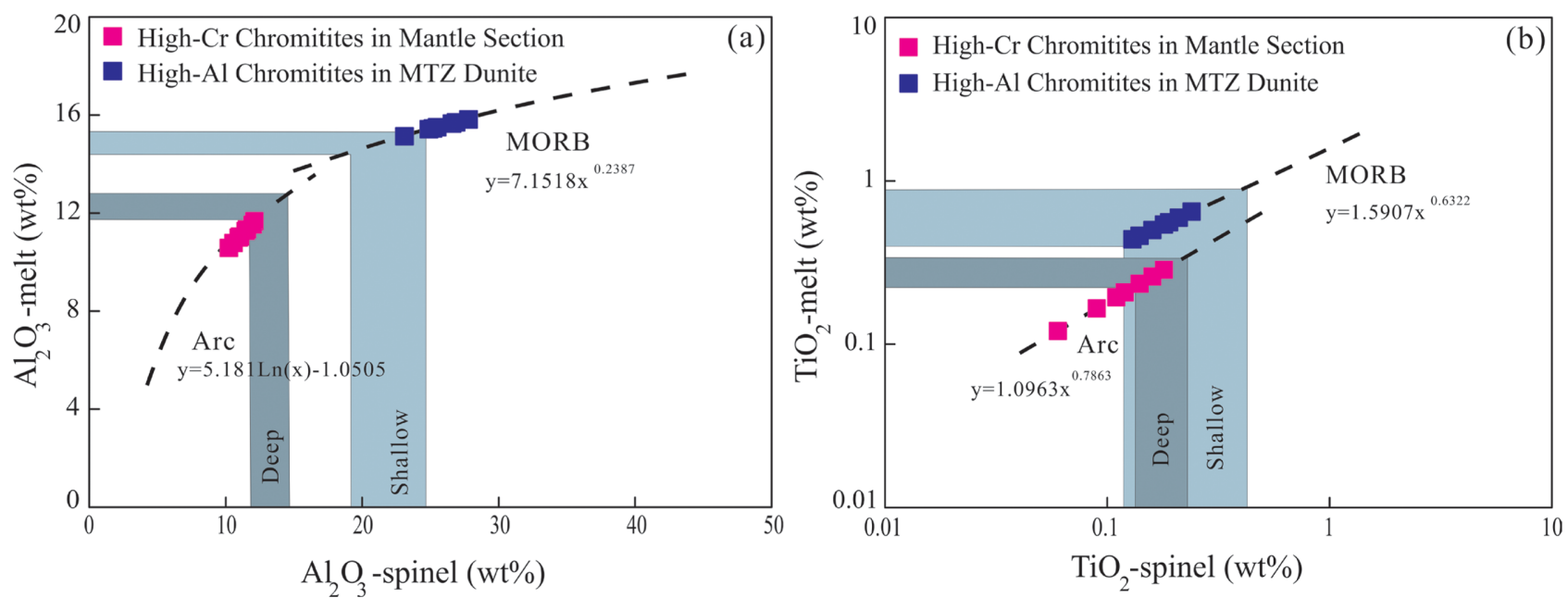

Figure 8. The parental melts (a) $\mathrm{Al}_{2} \mathrm{O}_{3}$ and (b) $\mathrm{TiO}_{2}$ contents are in equilibrium with the studied chromitites from Dargai Complex. The Arc and MORB lines are reported by Kamenetsky et al. (2001) and Rollinson (2008). The calculated melt compositions and the chromian spinel ranges from Dargai complex are shown as light blue green and ocean green fields.

and $\mathrm{Cr}$ contents in the mantle rocks (Zhou et al., 1998).

In Dargai Complex, the total PGE contents of both the high-Al and high-Cr chromitites are much higher than the concentrations of PGE in MTZ dunites, mantle dunites and harzburgites (Fig. 7a-b). It is gen- erally believed that platinum group elements are added in basaltic melts during partial melting of residual sulfide, and to a smaller extent alloys, that reside in the peridotites of mantle (Luguet et al., 2001; Alard et al., 2002; Bockrath et al., 2004; Lorand et al., 2010). Hence, 
the melts PGE compositions depend to a large extent on partial melting degrees. Due to the low degree of partial melting $(<20 \%)$, sulfides are usually retained in the mantle, so the PGE abundances of the melts is low, and any chromitites precipitated from such melts will also have very low PGE concentrations (some of ppb). On the other hand, melts produced by the high degrees of partial melting $(\geq 20 \%)$, are PGE enriched, leads to higher PGE abundances in the related chromitites (Economou-Eliopoulos, 1996; Zhou et al., 1998; Ahmed and Arai, 2002; O'Hara et al., 2002; Gervilla et al., 2005; Prichard et al., 2008; Proenza et al., 2008; Uysal et al., 2009b; Gonzalez-Jimenez et al., 2011). In Dargai Complex, the high-Al chromitites have similar, but slightly lower, total concentrations of PGEs from 39.1 to 200 ppb than the high-Cr chromitites ranging from 112 to $258 \mathrm{ppb}$ (Fig. 7a; Table 6). These outcomes illustrate that their magmas were both originated by relatively higher degree of partial melting, but probably the melts of high-Al chromitites were formed by somewhat low degrees of melting than the high-Cr types.

Under the conditions of sulfur under-saturation, PGEs distribution of podiform chromitites is basically consistent with initial chromite accumulation from mafic characteristics magmas. Early research on chromitites suggest that the stratiform chromitites are rich in PPGEs and have normalized PGE patterns with positive sloping chondrite, whereas podiform chromitites in ophiolites are IPGE-rich and have negative sloping pattern characteristics (Page et al., 1982; Page and
Talkington, 1984). Therefore, PPGE enriched podiform chromitites have since been studied from Philippines Zambales Ophiolite (Bacuta et al., 1988), Greece Pindos Ophiolite (Konstantopoulou and EconomouEliopoulos, 1991), Scotland Pt-and Pd-rich Ophiolite include Unst in the Shetland Island (Prichard and Lord, 1993), from Norway Leka Ophiolite (Pedersen et al., 1993) and from Saudi Arabia Al'Ays Ophiolite (Prichard et al., 2008). According to Prichard et al. (2008), chromium in the mantle can be liberated over a much higher partial melting range than the narrow critical melting interval at around 20 to $25 \%$ proposed for PPGE, which is considered for the largely variable PPGE concentrations of podiform chromitite. The high-Cr chromitites of Dargai Complex, are poor in PPGE concentrations comparative to IPGE with lower Pt/Ir ratio which is ranging from 0.02 to 1.49 (Table 6; Fig. 7c). This indicates that the degree of partial melting exceeded the critical interval, thus preventing sulfide saturation and diluting volatile PGE (i.e., Pt and Pd) in melting and is resulted in enrichment of PGEs chromitites, while Pt and Pd are particularly barren (Keays, 1995; Najafzadeh et al., 2008; Prichard et al., 2008; Gonzalez-Jimenez et al., 2011). Such explanations are consistent with the crystallization of high-Cr chromitites due to boninitic type magmas, which are sulfur under-saturated in composition (Zhou et al., 1998; Melcher et al., 1999; Ahmed et al., 2009).

In contrast, high-Al chromitites of the Dargai Complex are low in IPGE contents relative to PPGE with higher Pd/Ir ratio ranging from

Table 7. Calculated oxygen fugacities $\left(\mathrm{fO}_{2}\right)$ of Dargai Complex peridotites and chromitites

\begin{tabular}{|c|c|c|c|c|c|c|c|c|c|}
\hline Lithology & S. No & Spinel Cr\# & Spinel Mg\# & ${\mathrm{Spinel} \mathrm{Fe}^{3+} / \sum \mathrm{Fe}}$ & Olivine $\mathrm{Mg} \#$ & Temp (K) & $\Delta \log \left(\mathrm{fO}_{2}\right) \mathrm{FMQ}$ & Spinel $\mathrm{Fe}^{3+} \#$ & Spinel $\mathrm{TiO}_{2}(\mathrm{wt} \%)$ \\
\hline \multirow{5}{*}{ Harzburgite } & SQ4-1 & 74.2 & 39.5 & 0.053 & 89.6 & 924.5 & -1.759 & 0.016 & 0.08 \\
\hline & SQ4-2 & 73.2 & 41.7 & 0.104 & 89.2 & 961.8 & -0.650 & 0.033 & 0.05 \\
\hline & SQ4-3 & 77.5 & 48.1 & 0.194 & 88.6 & 1111.1 & 0.157 & 0.059 & 0.07 \\
\hline & SQ4-4 & 72.2 & 45.6 & 0.093 & 88.7 & 1010.1 & -1.120 & 0.027 & 0.05 \\
\hline & SQ4-5 & 75.6 & 47.3 & 0.188 & 88.9 & 1072.2 & 0.214 & 0.059 & 0.06 \\
\hline \multirow{5}{*}{ Mantle Dunite } & SQ5-1 & 79.8 & 40.5 & 0.168 & 91.9 & 910.1 & 0.962 & 0.060 & 0.12 \\
\hline & SQ5-2 & 82.6 & 42.0 & 0.169 & 91.7 & 949.5 & 0.839 & 0.060 & 0.15 \\
\hline & SQ5-3 & 80.1 & 46.9 & 0.238 & 91.0 & 1015.0 & 1.263 & 0.085 & 0.14 \\
\hline & SQ5-4 & 81.6 & 46.0 & 0.127 & 91.0 & 994.7 & -0.043 & 0.040 & 0.17 \\
\hline & SQ5-5 & 81.0 & 42.6 & 0.165 & 91.9 & 937.4 & 0.841 & 0.057 & 0.16 \\
\hline \multirow{5}{*}{ MTZ Dunite } & HS4-1 & 46.7 & 66.8 & 0.335 & 89.5 & 1142.8 & 1.093 & 0.086 & 0.17 \\
\hline & HS4-2 & 48.9 & 59.5 & 0.323 & 88.7 & 1065.2 & 1.303 & 0.099 & 0.19 \\
\hline & HS4-3 & 49.4 & 67.3 & 0.460 & 89.8 & 1207.4 & 1.976 & 0.147 & 0.22 \\
\hline & HS4-4 & 48.9 & 59.8 & 0.312 & 89.2 & 1050.6 & 1.278 & 0.093 & 0.18 \\
\hline & HS4-5 & 48.3 & 59.4 & 0.316 & 89.7 & 1024.0 & 1.453 & 0.096 & 0.19 \\
\hline \multirow{5}{*}{$\begin{array}{l}\text { High-Cr } \\
\text { Chromitite }\end{array}$} & SQ1-1 & 80.8 & 69.3 & 0.264 & 94.2 & 1195.6 & 1.122 & 0.056 & 0.16 \\
\hline & SQ1-2 & 79.7 & 69.4 & 0.279 & 94.8 & 1145.2 & 1.487 & 0.061 & 0.18 \\
\hline & SQ1-3 & 81.9 & 74.4 & 0.393 & 94.3 & 1407.7 & 1.491 & 0.075 & 0.11 \\
\hline & SQ1-4 & 79.1 & 69.3 & 0.234 & 94.2 & 1178.2 & 0.834 & 0.047 & 0.14 \\
\hline & SQ1-5 & 81.4 & 71.3 & 0.361 & 95.1 & 1239.4 & 1.852 & 0.073 & 0.06 \\
\hline \multirow{5}{*}{$\begin{array}{l}\text { High-Al } \\
\text { Chromitite }\end{array}$} & HS2-1 & 47.5 & 64.2 & 0.245 & 89.4 & 1071.6 & 1.533 & 0.060 & 0.13 \\
\hline & HS2-2 & 50.7 & 71.3 & 0.238 & 88.4 & 1337.9 & 0.427 & 0.045 & 0.19 \\
\hline & HS2-3 & 48.4 & 73.1 & 0.274 & 91.7 & 1166.8 & 0.562 & 0.053 & 0.14 \\
\hline & HS2-4 & 52.2 & 65.8 & 0.260 & 91.8 & 1051.0 & 0.979 & 0.061 & 0.24 \\
\hline & HS2-5 & 53.0 & 68.2 & 0.420 & 88.5 & 1316.0 & 1.269 & 0.119 & 0.14 \\
\hline
\end{tabular}

Formula units are based on $\mathrm{O}=32$ and $\mathrm{Fe}^{2+} / \mathrm{Fe}^{3+}$ assuming full site occupancy. $\mathrm{Cr} \#=100 \times \mathrm{Cr} /(\mathrm{Cr}+\mathrm{Al}) ; \mathrm{Mg} \#=100 \times \mathrm{Mg} /\left(\mathrm{Mg}+\mathrm{Fe} e^{2+}\right) ; \mathrm{Fe}^{3+} \#=100 \times$ $\mathrm{Fe}^{3+} /\left(\mathrm{Fe}^{3+}+\mathrm{Cr}+\mathrm{Al}\right) ;$ Spinel $\mathrm{Fe}^{3+} / \mathrm{Fe}=\mathrm{Fe} 3+/\left(\mathrm{Fe}^{3+}+\mathrm{Fe}^{2+}\right)$. S.No $=$ number of samples; Tem $\mathrm{p}=$ temperature; $\mathrm{FMQ}=$ fayalite-magnetite-quartz buffer. 
3.43 to 43.2 (Table 6; Fig. 7c). This shows that degree of partial melting of the mantle sources were just within the critical range of 20 to $25 \%$, which could have effectively extracted PGEs from mantle sulfides, but were not high enough to dilute the parental melts in the refractory elements (PPGEs) (Prichard et al., 2008; Gonzalez-Jimenez et al., 2011).

\section{Tectonic Setting of Chromitites and Peridotites of Dargai Complex}

The coexistence of both high- $\mathrm{Cr}$ and high-Al chromitites in the same ophiolitic block has been commonly interpreted as reflecting different melt activities that originated from different mantle sources in different tectonic environments (Zhou et al., 1994, 1996, 1998; Economou-Eliopoulos, 1996; Proenza et al., 1999; Ahmed and Arai, 2002; Rollinson, 2008; Tsoupas and Economou-Eliopoulos, 2008). Although, the progressive evolution of parental melts during melt-rock reaction or via melt-migration in supra-subduction zone (SSZ) environment can also provide interpretation for the coexistence of both high-Cr and high-Al chromitites in a single ophiolitic belt (Leblanc, 1995; Graham et al., 1996; Melcher et al., 1997; Ahmed and Arai, 2002; Rollinson, 2005; Uysal et al., 2009a).

In the Dargai Complex, the mantle section comprises high-Cr chromitites, whereas mantle-crust transition zone (MTZ) encloses the high-Al chromitites at higher level. Chemical characteristics of chromian spinel such as high $\mathrm{Cr} \#$ values (78.4 to 81.9$)$ and low $\mathrm{TiO}_{2}$ (0.06 to $\left.0.18 \mathrm{wt} \%\right)$ and $\mathrm{Al}_{2} \mathrm{O}_{3}(8.65$ to $10.6 \mathrm{wt} \%)$ contents for the parental melts of high-Cr chromitites suggest that in Dargai Complex the high-Cr chromitites were formed from parental melt with boninitic composition related to supra-subduction zone (SSZ) tectonic environment. However, chromian spinels in the high-Al chromitites fall in the mid-ocean ridge basalt (MORB) field based on $\mathrm{Cr} \#$ ranging from 47.5 to $52.9, \mathrm{Mg} \#$ from 64.2 to 73.1 and $\mathrm{TiO}_{2}$ from 0.13 to $0.24 \mathrm{wt} \%$. These concentrations of chromian spinel in the high-Al chromitites are distinguished by a continuous and large spectrum, with some values plotted at the border of MORB field (Fig. 5d).

The high-Al chromitites display a continuous spectrum of calculated $\mathrm{TiO}_{2}$ concentrations of the parental melts lower than typical MORB melts (Fig. 8b), which suggests that the MORB magmas have a less role in formation of high-Al chromitites. Other than that, the presence of hydrous silicate inclusions (Fig. 3f-g) and their high oxygen fugacities (Fig. 9) in the chromian spinel of the high-Al chromitites shows that they are formed by typical supra-subduction zone (SSZ) from the hydrous oxidized and low $\mathrm{TiO}_{2}$ magma. It is consistent with the degree of high partial melting assumed for the creation of high-Al chromitites parental melts (20 to $25 \%$ ), which is greater than the average degrees of partial melting (10 to 20\%) for mid-ocean ridge basalt (MORB) magma (Klein and Langmuir 1987; Hofmann, 1988), but within the scope of supra-subduction zone (SSZ) tectonic environment melt (Prichard et al., 2008). Thus it is proposed that the high-Al chromitites of Heru-Shah have been generated at a spreading center in a supra-subduction zone (SSZ) setting.

Recent research on the Izu-Bonin-Mariana (IBM) arc system, estab-

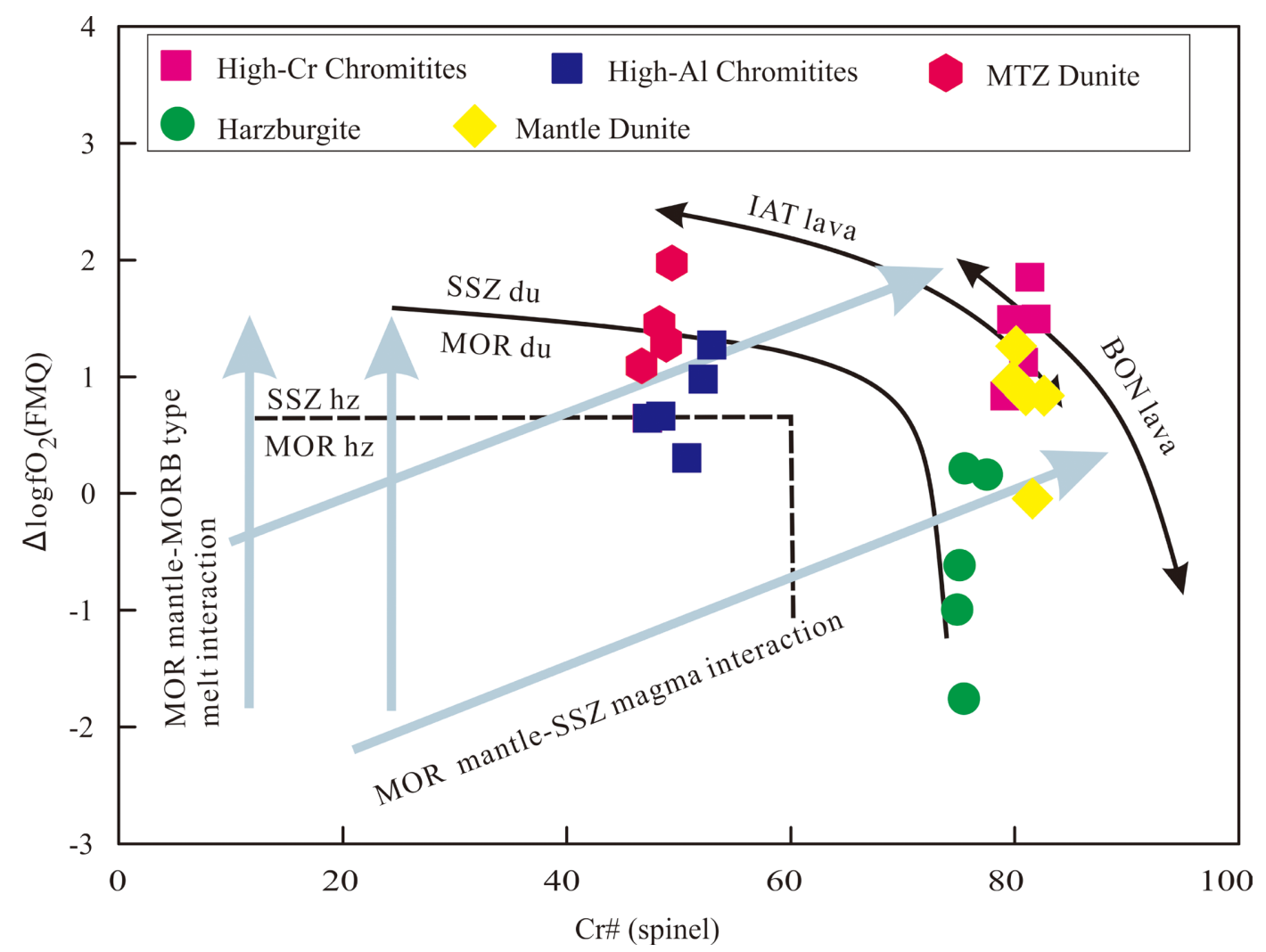

Figure 9. Plot of $\triangle \operatorname{logfo}_{2}$ (FMQ) vs. Cr\# of chromian spinel from the high-Cr and high-Al chromitites, harzburgites, mantle dunites and mantlecrust transition zone dunites of the Dargai Complex. The Alogfo ${ }_{2}$ (Ballhaus et al., 1991) values have been calculated from geothermometric data derived from olivine-spinel equilibria following the approach of Wan et al. (2008); the data are provide in Table 7. MOR-SSZ discrimination boundaries for dunites (solid line) and harzburgite (dashed line) are shown. MOR (mid ocean ridge), SSZ (supra-subduction zone), BON (boninite), IAT (island arc tholeiite) (Parkinson and Pearce, 1998; Dare et al., 2009). 
lished that there is existence of chemical transition of lavas between the forearc-basalt and boninite (Reagan et al., 2010; Li et al., 2013; Brounce et al., 2015). The changing mid-ocean ridge basalt (MORB) magmas composition to boninitic type could explain the higher range of Cr\#s in chromian spinel in the Izu-Bonin-Mariana (IBM) forearc mantle (Morishita et al., 2011a; Tamura et al., 2016). In the other hand, the existence of MORB like and boninitic type magmas in the Dargai Complex indicates a two-phase process of magmatism, which usually occurs in a proto-forearc spreading during the initiation of subduction (Ahmed, 1982, 1984; Arif and Jan, 2006). The first phase is characterized by upwelling of asthenosphere over the sinking oceanic slab generating MORB like melts, which are Ti rich. Both the chromian spinels in the MTZ dunites and pyroxenes and amphibole inclusion in high-Al chromitites spinels having comparatively higher $\mathrm{TiO}_{2}$ contents are well-matched to such a model (Fig. 5d, 6b, 6e). In the second phase, the parental melts altered from MORB type to boninitic type in chemical characteristics as the proto-forearc environment evolves into a forearc setting, causing the crystallization of high-Al chromitites and then high-Cr chromitites. These processes can describe the relationships observed in Dargai Complex Ophiolite which are well-matched with the models proposed by some authors (Morishita et al., 2011b; Qiu et al., 2018), who presented distinct peridotite (harzburgites and dunites) in the mantle section and concluded that clinopyroxene bearing harzburgite rocks in the mantle section are a residues associated to MORB type forearc basalt. This model shows that, the highly refractory harzburgites, mantle dunites (and chromitites) may have genetically associated to boninitic type magma in the mantle-wedge, and by interaction with transitional melt between MORB and boninitic types magmas, some spinel bearing dunites may have usually formed. Hence, our preliminary conclusions is that the lithological variation and the two kinds of chromitites in the Dargai Complex reflect evolutions in magma composition from MORB type to boninitic type during subduction initiation process.

\section{Conclusions}

The petrography, mineralogy and geochemistry based on the chromian spinel and platinum group elements of the chromitites and peridotites of the Dargai Complex suggest that the high-Cr chromitites were existed in peridotites (harzburgites and dunites) of the mantle section, while high-Al chromitites were hosted in the mantle-crust transition zone (MTZ) massive dunites.

The total PGE concentrations in high-Cr chromitites indicate that these are higher in IPGE than that of the high-Al chromitites. For the parental magma of the high-Cr chromitites, these differences are related to the higher degree $(>25 \%)$ of partial melting, which prevented the saturation of sulfides and caused the dilution of $\mathrm{Pt}$ and $\mathrm{Pd}$ in the parental magma. The high-Al chromitites parental magmas were produced at lower degree (20-25\%) of partial melting, which could have effectively extracted the PGE from the mantle sulfide and as a result caused PPGE enrichment in high-Al chromitites type.

In the Dargai Complex, the coexistence of high-Cr chromitites and high-Al chromitites suggests that the compositions of magmas evolved from MORB type to boninitic type in a proto-forearc setting during subduction initiation. The transitional lavas, which are generally MORB type with affinities of low $\mathrm{TiO}_{2}$, oxidized and hydrous nature, could have been the parental magma of high-Al chromitites, whereas boninitic type melts could have been responsible for the formation of high-Cr chromitites.

\section{Acknowledgements}

This research was financially supported by a grant from the National Natural Science Foundation of China (No. 41325007) and State Key Laboratory of Geological Processes and Mineral Resources (MSFGPMR03) during the $\mathrm{PhD}$ studies of the first author in the China University of Geosciences, Wuhan, China. We are grateful to Prof. Paul T. Robinson (Dalhousie University) for correcting grammatical and syntax errors. We thank Aminullah Kakar and an anonymous reviewer for their useful comments and suggestions which helped improve the presentation of the manuscript. Our thanks extend to chief editor Dr. Jin-Yong Lee for handling the manuscript.

\section{References}

Ahmad, I., Lawrence, R.D., and DiPietro, J.A., 1998, Olistostromal blocks in metamorphosed Saidu melange, Malakand Agency, North Pakistan. In: Hamidullah, S., Lawrence, R. D., Jan, M.Q. (Eds.), Proceedings of the 13th HKT International Workshop. Geological Bulletin University of Peshawar, Special Publication, 31, pp. 1-3.

Ahmadi, M.H., and Molladavoodi, H., 2018, Rock Failure Analysis under Dynamic Loading Based on a Micromechanical Damage Model. Civil Engineering Journal, v. 4, pp. 2801-2812. doi:org/10.28991/cej-03091199.

Ahmed, Z., 1988, Bulk-rock chemistry and petrography of the SkhakotQila ophiolite, Pakistan. Acta Mineralogica Pakistanica, v. 4, pp. 4-29.

Ahmed, Z., 1982, Porphyritic-nodular, nodular, and orbicular chrome ores from the Sakhakot-Qila complex Pakistan, and their chemical variations. Mineralogical Magazine, v. 45, pp. 167-178. doi:org/10.1180/minmag. 1982.045.337.20.

Ahmed, Z., 1984, Stratigraphic and Textural Variations in the Chromite Composition of the Ophiolitic Sakhakot-Qila Complex, Pakistan. Economic Geology, v. 79, pp. 1334-1359. doi:org/10.2113/gsecongeo.79.6.1334.

Ahmed, A.H., and Arai, S., 2002, Unexpectedly high-PGE chromitite from the deeper mantle section of the northern Oman ophiolite and its tectonic implications. Contributions to Mineralogy and Petrology, v. 143, pp. 263-278. doi:org/10.1007/s00410-002-0347-8.

Ahmed, A.H., Arai, S., Abdel-Aziz, Y.M., Ikenne, M., and Rahimi, A., 2009, Platinum-group elements distribution and spinel composition in podiform chromitites and associated rocks from the upper mantle section of the Neoproterozoic Bou Azzer ophiolite, Anti-Atlas, Morocco. Journal of African Earth Sciences, v. 55, pp. 92-104. doi:org/10.1016/ j.jafrearsci.2009.02.005.

Alard, O., Griffin, W. L., Pearson, D. G., Lorand, J.P., and O'Reilly, S.Y., 2002, New insights into the Re-Os systematics of sub-continental lithospheric mantle from in-situ analysis of sulphides. Earth and Planetary Science Letters, v. 203, pp. 651-663. doi:org/10.1016/S0012-821X (02)00799-9.

Arai, S., 1992, Chemistry of chromian spinel in volcanic rocks as a potential guide to magma chemistry. Mineralogical Magazine, v. 56, pp. 173-184. doi:org/10.1180/minmag.1992.056.383.04.

Arai, S., Kadoshima, K., and Morishita, T., 2006, Widespread arc-related melting in the mantle section of the northern Oman ophiolite as inferred from detrital chromian spinels. Journal of the Geological Society, v. 163, pp. 869-879. doi:org/10.1144/0016-76492005-057.

Arai, S., and Miura, M., 2016, Formation and modification of chromitites 
in the mantle. Lithos, v. 264, pp. 277-295. doi:org/10.1016/j.lithos. 2016.08.039.

Arai, S., Okamura, H., Kadoshima, K., Tanaka, C., Suzuki, K., and Ishimaru, S., 2011, Chemical characteristics of chromian spinel in plutonic rocks: Implications for deep magma processes and discrimination of tectonic setting. Island Arc, v. 20, pp. 125-137. doi:org/10.1111/j.14401738.2010.00747.x

Arif, M., and Jan, M.Q., 2006, Petrotectonic significance of the chemistry of chromite in the ultramafic-mafic complexes of Pakistan. Journal of Asian Earth Sciences, v. 27, pp. 628-646. doi:org/10.1016/j.jseaes. 2005.06.004

Arasaretnam, S., and Kirudchayini, T., 2019, Studies on Synthesis, Characterization of Modified Phenol Formaldehyde Resin and Metal Adsorption of Modified Resin Derived From Lignin Biomass. Emerging Science Journal, v. 3, pp. 101-108. doi:org/10.28991/esj-2019-01173.

Asrarullah., Ahmad, Z., and Abbas, S.G., 1979, Active fault system in Pakistan. In: Farah, A., and DeJong, K. A. (Eds.), Geodynamics of Pakistan. Geological Survey of Pakistan, Quetta, pp. 181-192.

Avcı, E., Uysal, İ., Akmaz, R.M., and Saka, S., 2017, Ophiolitic chromitites from the Kızılyüksek area of the Pozantı-Karsantı ophiolite (Adana, southern Turkey): Implication for crystallization from a fractionated boninitic melt. Ore Geology Reviews, v. 90, pp. 166-183. doi:org/10.1016/ j.oregeorev.2016.08.033.

Bacuta, G.C., Lipin, B.R., Gibbs, A.K., and Kay, R.W., 1988, PlatinumGroup Element Abundance in Chromite Deposits of the Acoje Ophiolite Block, Zambales Ophiolite Complex, Philippines. Geo-Platinum, v. 87, pp. 381-382. doi:org/10.1007/978-94-009-1353-0_39.

Ballhaus, C., 1998, Origin of podiform chromite deposits by magma mingling. Earth and Planetary Science Letters, v. 156, pp. 185-193. doi:org/ 10.1016/S0012-821X(98)00005-3.

Ballhaus, C., Berry R.f., and Green D. H., 1991, High pressure experimental calibration of the olivine-orthopyroxene-spinel oxygen geobarometer: implications for the oxidation state of the upper mantle. Contributions to Mineralogy and Petrology, v. 107, pp. 27-40. doi:org/10.1007/bf00311183.

Bao, P.S., Wang, X.B., Peng, G.Y., and Chen, F.Y., 1999, Chromite Deposit in China, Beijing Science and Technology Publishing House, 108-135 p (in Chinese).

Bard, J.P., 1983, Metamorphism of an obducted island arc: example of the Kohistan sequence (Pakistan) in the Himalayan collided range. Earth and Planetary Science Letters, v. 65, pp. 133-144. doi:org/10.1016/0012821X(83)90195-4.

Barnes, S.J., Naldrett, A.J., and Gorton, M.P., 1985, The origin of the fractionation of platinum-group elements in terrestrial magmas. Chemical Geology, v. 53, pp. 303-323. doi:org/10.1016/0009-2541(85) 90076-2.

Barnes, S.J., and Roeder, P.L., 2001, The Range of Spinel Compositions in Terrestrial Mafic and Ultramafic Rocks. Journal of Petrology, v. 42, pp. 2279-2302. doi:org/10.1093/petrology/42.12.2279.

Bockrath, C., Ballhaus, C., and Holzheid, A., 2004, Stabilities of laurite $\mathrm{RuS}_{2}$ and monosulfide liquid solution at magmatic temperature. Chemical Geology, v. 208, pp. 265-271. doi:org/10.1016/j.chemgeo.2004.04.016.

Brounce, M., Kelley, K.A., Cottrell, E., and Reagan, M.K., 2015, Temporal evolution of mantle wedge oxygen fugacity during subduction initiation. Geology, v. 43, pp. 775-778. doi:org/10.1130/g36742.1.

Burg, J.P., Bodinier, J.L., Chaudhry, S., Hussain, S., and Dawood, H., 1998, Infra-arc mantle-crust transition and intra-arc mantle diapirs in the Kohistan Complex (Pakistani Himalaya): Petro-structural evidence. Terra Nova, v. 10, pp. 74-80. doi:org/10.1046/j.1365-3121.1998. 00170.x.

Cottrell, E., and Kelley, K.A., 2011, The oxidation state of Fe in MORB glasses and the oxygen fugacity of the upper mantle. Earth and Planetary Science Letters, v. 305, pp. 270-282. doi:org/10.1016/j.epsl. 2011.03.014.

Dare, S.A., Pearce, J.A., McDonald, I., and Styles, M.T., 2009, Tectonic discrimination of peridotites using $\mathrm{fO}_{2}-\mathrm{Cr} \#$ and $\mathrm{Ga}-\mathrm{Ti}-\mathrm{Fe}$ III systematics in chrome-spinel. Chemical Geology, v. 261, pp. 199-216. doi:org/ 10.1016/j.chemgeo.2008.08.002.

Dick, H.J.B., and Bullen, T., 1984, Chromian spinel as a petrogenetic indi- cator in abyssal and alpine-type peridotites and spatially associated lavas. Contributions to Mineralogy and Petrology, v. 86, pp. 54-76. doi:org/ 10.1007/bf00373711.

DiPitero, J. A., Hussain, A., Ahmad, A., and Khan, M.A., 2000, The main mantle thrust in Pakistan: its character and extent. In: Khan, M.A., Treloar, P.J., Searle, M.P., and Jan, M.Q. (Eds.), Tectonics of the Nanga Parbat Syntaxis and the Western Himalaya. Geological Society of London, Special Publication, v. 170, pp. 375-393. doi:org/10.1144/gsl.sp. 2000.170.01.20.

Economou-Eliopoulos, M., 1996, Platinum-group element distribution in chromite ores from ophiolite complexes: Implications for their exploration. Ore Geology Reviews, v. 11, pp. 363-381. doi:org/10.1016/s01691368(96)00008-x.

Esmailzadeh, A., Behnam, S., Mikaeil, R., Naghadehi, M.Z., and Saei, S., 2017, Relationship between Texture and Uniaxial Compressive Strength of Rocks. Civil Engineering Journal, v. 3, pp. 480-486. doi:org/10.28991/ cej-2017-00000106

Fareeduddin., and Dilek, Y., 2015, Structure and petrology of the Nagaland-Manipur Hill Ophiolitic Mélange zone, NE India: A Fossil Tethyan Subduction Channel at the India - Burma Plate Boundary. Episodes, v. 38, pp. 298-314. doi:org/10.18814/epiiugs/2015/v38i4/82426.

Gervilla, F., Proenza, J.A., Frei, R., González-Jiménez, J.M., Garrido, C.J., Melgarejo, J.C., Meibom, A., Díaz-martínez, R., and Lavaut, W., 2005, Distribution of platinum-group elements and Os isotopes in chromite ores from Mayarí-Baracoa Ophiolitic Belt (eastern Cuba). Contributions to Mineralogy and Petrology, v. 150, pp. 589-607. doi:org/10.1007/ s00410-005-0039-2.

González-Jiménez, J.M., Griffin, W.L., Proenza, J.A., Gervilla, F., O'Reilly, S.Y., Akbulut, M., Pearson, N.J., and Arai, S., 2014, Chromitites in ophiolites: How, where, when, why? Part II. The crystallization of chromitites. Lithos, v. 189, pp. 140-158. doi:org/10.1016/j.lithos. 2013.09.008.

González-Jiménez, J.M., Proenza, J.A., Gervilla, F., Melgarejo, J.C., Blanco-Moreno, J.A., Ruiz-Sánchez, R., and Griffin, W.L., 2011, High-Cr and high-Al chromitites from the Sagua de Tánamo district, MayaríCristal ophiolitic massif (eastern Cuba): Constraints on their origin from mineralogy and geochemistry of chromian spinel and platinum-group elements. Lithos, v. 125, pp. 101-121. doi:org/10.1016/j.lithos. 2011.01.016.

Graham, I.T., Franklin, B.J., and Marshall, B., 1996, Chemistry and mineralogy of podiform chromitite deposits, southern NSW, australia: a guide to their origin and evolution. Mineralogy and Petrology, v. 57, pp. 129-150. doi:org/10.1007/bf01162355.

Hickey, R.L., and Frey, F.A., 1982, Geochemical characteristics of boninite series volcanics: implications for their source. Geochimica et Cosmochimica Acta, v. 46, pp. 2099-2115. doi:org/10.1016/0016-7037(82) 90188-0.

Hofmann, A.W., 1988, Chemical differentiation of the Earth: the relationship between mantle, continental crust, and oceanic crust. Earth and Planetary Science Letters, v. 90, pp. 297-314. doi:org/10.1016/0012$821 x(88) 90132-x$.

Irvine, T.N., 2009, Chromian Spinel As a Petrogenetic Indicator: Part 2. Petrologic Applications. Canadian Journal of Earth Sciences, v. 4, pp. 71-103. doi:org/10.1139/e67-004.

Ishii, T., Robinson, P.T., Maekawa, H., and Fiske, R., 1992, Petrological studies of peridotites from diapiric serpentinite seamounts in the IzuOgasawara-Mariana forearc, Leg 125. In: Fryer, P., Pearce, J.A., and Stokking, L.B. (Eds.), Proceedings of the Ocean Drilling Program. Scientific Results, 125, pp. 445-485. doi:org/10.2973/odp.proc.sr. 125.129.1992.

Jackson, S.E., Fryer, B.J., Gosse, W., Healey, D.C., Longerich, H.P., and Strong, D.F., 1990, Determination of the precious metals in geological materials by inductively coupled plasma-mass spectrometry (ICP-MS) with nickel sulphide fire-assay collection and tellurium coprecipitation. Chemical Geology, v. 83, pp. 119-132. doi:org/10.1016/0009-2541(90) 90144-v.

Jan, M.Q., 1979, Petrography of the Jijal Complex, Kohistan. In: Tahirkheli, R.A.K., and Jan, M.Q. (Eds.), Geology of Kohistan, Karakoram Hima- 
laya, Northern Pakistan. Geological Bulletin University of Peshawar, 11, pp. 31-49.

Jan, M.Q., Khan, M.A., and Qazi, M.S., 1993, The Sapat mafic-ultramafic complex, Kohistan arc, North Pakistan. Geological Society of London, Special Publications, 74, pp. 113-121. doi:org/10.1144/gsl.sp. 1993.074. 01.09 .

Kamenetsky, V.S., Crawford, A.J., and Meffre, S., 2001, Factors Controlling Chemistry of Magmatic Spinel: an Empirical Study of Associated Olivine, Cr-spinel and Melt Inclusions from Primitive Rocks. Journal of Petrology, v. 42, pp. 655-671. doi:org/10.1093/petrology/ 42.4.655.

Kazmi, A.H., Lawrence, R.D., Anwar, J., Snee, L.W., and Hussain, S., 1986, Mingora emerald deposits (Pakistan): suture-associated mineralization. Economic Geology, v. 81, pp. 2022-2028. doi:org/10.2113/ gsecongeo.81.8.2022.

Kazmi, A.H., Lawrence, R.D., Dawood, H., Snee, L.W., and Hussain, S.S., 1984, Geology of the Indus suture zone in the Mingora-Shangla area of Swat, N. Pakistan. Geological Bulletin University of Peshawar, v. 17, pp. 127-144.

Keays, R.R., 1995, The role of komatiitic and picritic magmatism and Ssaturation in the formation of ore deposits. Lithos, v. 34, pp. 1-18. doi:org/10.1016/0024-4937(95)90003-9.

Klein, E. M., and Langmuir, C.H., 1987, Global Correlations of Ocean Ridge Basalt Chemistry with Axial Depth and Crustal Thickness. Journal of Geophysical Research, v. 92, pp. 8089-8115. doi:org/10.1029/ jb092ib08p08089.

Konstantopoulou, G., and Economou-Eliopoulos, M., 1991, Distribution of platinum-group elements and gold within the Vourinos chromitite ores, Greece. Economic Geology, v. 86, pp. 1672-1682. doi:org/10.2113/ gsecongeo.86.8.1672.

Kyere, V.N., Greve, K., Atiemo, S.M., Amoako, D., Aboh, I.K., Cheabu, B.S., 2018, Contamination and Health Risk Assessment of Exposure to Heavy Metals in Soils from Informal E-Waste Recycling Site in Ghana. Emerging Science Journal, v. 2, pp. 428-436. doi:org/10.28991/esj2018-01162.

Leblanc, M., 1995, Chromitite and ultramafic rock compositional zoning through a paleotransform fault, Poum, New Caledonia. Economic Geology, v. 90, pp. 2028-2039. doi:org/10.2113/gsecongeo.90.7.2028.

Li, Y.B., Kimura, J.I., Machida, S., Ishii, T, Ishiwatari, A., Maruyama, S., Qiu, H.N., Ishikawa, T., Kato, Y., Haraguchi, S., Takahata, N., Hirahara, Y., and Miyazaki, T., 2013, High-Mg adakite and low-Ca boninite from a bonin fore-arc seamount: Implications for the reaction between slab melts and depleted mantle. Journal of Petrology, v. 54, pp. 11491175. doi:org/10.1093/petrology/egt008.

Lian, D., Yang, J., Dilek, Y., Wu, W., Zhang, Z., Xiong, F., Liu, F., and Zhou, W., 2017, Deep mantle origin and ultra-reducing conditions in podiform chromitite: Diamond, moissanite, and other unusual minerals in podiform chromitites from the Pozanti-Karsanti ophiolite, southern Turkey. American Mineralogist, v. 102, pp. 1101-1113. doi:org/10.2138/ am-2017-5850.

Liang, Q., Jing, H., and Gregoire, D.C., 2000, Determination of trace elements in granites by inductively coupled plasma mass spectrometry. Talanta, v. 51, pp. 507-513. doi:org/10.1016/s0039-9140(99)00318-5.

Liu, X., Su, B., Bai, Y., Chen, C., Xiao, Y., Liang, Z., Yang, S., Peng, Q., $\mathrm{Su}, \mathrm{B}$., and Liu, B., 2018, Ca-Enrichment Characteristics of Parental Magmas of Chromitite in Ophiolite: Inference from Mineral Inclusions. Journal of Earth Science, v. 43, pp. 1038-1050.

Llanes, A.I., Proenza, J.A., Zaccarini, F., Garuti, G., Santa Cruz Pacheco, M., 2015, Al- and Cr-rich chromitites from the Eastern Havana-Matanzas ophiolites (Western Cuba). Episodes, v. 38, pp. 334-343. doi:org/ 10.18814/epiugs/2015/v38i4/82429.

Lorand, J.P., Alard, O., and Luguet, A., 2010, Platinum-group element micronuggets and refertilization process in Lherz orogenic peridotite (northeastern Pyrenees, France). Earth and Planetary Science Letters, v. 289, pp. 298-310. doi:org/10.1016/j.eps1.2009.11.017.
Luguet, A., Alard, O., Lorand, J.P., Pearson, N.J., Ryan, C., and O'Reilly, S.Y., 2001, Laser-ablation microprobe (LAM)-ICPMS unravels the highly siderophile element geochemistry of the oceanic mantle. Earth and Planetary Science Letters, v. 189, pp. 285-294. doi:org/10.1016/ s0012-821X(01)00357-0.

Matsumoto, I., and Arai, S., 2001, Morphological and chemical variations of chromian spinel in dunite-harzburgite complexes from the Sangun zone (SW Japan): Implications for mantle/melt reaction and chromitite formation processes. Mineralogy and Petrology, v. 73, pp. 305-323. doi:org/10.1007/s007100170004.

McDonough, W. F., and Sun, S.S., 1995, The composition of the earth. Chemical Geology, v. 120, pp. 223-253. doi:org/10.1016/0009-2541(94) 00140-4.

Melcher, F., Grum, W., Simon, G., Thalhammer, T. V., and Stumpfl, E.F., 1997, Petrogenesis of the ophiolitic giant chromite deposits of Kempirsai, Kazakhstan: A study of solid and fluid inclusions in chromite. Journal of Petrology, v. 38, pp. 1419-1458. doi:org/10.1093/petroj/38.10.1419.

Melcher, F., Grum, W., Thalhammer, T. V., and Thalhammer, O.A.R., 1999, The giant chromite deposits at Kempirsai, Urals: Constraints from trace element (PGE, REE) and isotope data. Mineralium Deposita, v. 34, pp. 250-272. doi:org/10.1007/s001260050202.

Miller, D.J., and Christensen, N.L., 1994, Seismic signature and geochemistry of an island arc: A multidisciplinary study of the Kohistan accreted terrane, northern Pakistan. Journal of Geophysical Research: Solid Earth, v. 99, pp. 11623-11642. doi:org/10.1029/94jb00059.

Miura, M., Arai, S., Ahmed, A.H., Mizukami, T., Okuno, M., and Yamamoto, S., 2012, Podiform chromitite classification revisited: A comparison of discordant and concordant chromitite pods from Wadi Hilti, northern Oman ophiolite. Journal of Asian Earth Sciences, v. 59, pp. 52-61. doi:org/10.1016/j.jseaes.2012.05.008.

Morishita, T., Dilek, Y., Shallo, M., Tamura, A., and Arai, S., 2011a, Insight into the uppermost mantle section of a maturing arc: The Eastern Mirdita ophiolite, Albania. Lithos, v. 124, pp. 215-226. doi:org/10.1016/j.lithos. 2010.10.003.

Morishita, T., Tani, K., Shukuno, H., Harigane, Y., Tamura, A., Kumagai, H., and Hellebrand, E., 2011b, Diversity of melt conduits in the IzuBonin-Mariana forearc mantle: Implications for the earliest stage of arc magmatism. Geology, v. 39, pp. 411-414. doi:org/10.1130/g31706.1.

Najafzadeh, A.R., Arvin, M., and Ahmadipour, H., 2008, Podiform Chromitites in the Sorkhband Ultramafic Complex, Southern Iran: Evidence for Ophiolitic Chromitite. Journal of Science Islamic Republic of Iran, v. 19 , pp. 49-65.

Naldrett, A.J., and Duke, J.M., 1980, Platinum metals in magmatic sulfide ores. Science, v. 208, pp. 1417-1424. doi:org/10.1126/science. 208.4451.1417.

Nkansah, M.A., Shamsu-Deen, M., and Opoku, F., 2018, Phytocompounds, Heavy Metal and Mineral Contents in honey Samples from Selected Markets in the Kumasi Metropolis. Emerging Science Journal, v. 2, pp. 287-294. doi:org/10.28991/esj-2018-01152.

O'Hara, M.J., Fry, N., and Prichard, H.M., 2002, Minor Phases as Carriers of Trace Elements in Non-Modal Crystal-Liquid Separation Processes I: Basic Relationships. Journal of Petrology, v. 42, pp. 1869-1885. doi:org/10.1093/petrology/42.10.1869.

Page, P., and Barnes, S.J., 2009, Using trace elements in chromites to constrain the origin of podiform chromitites in the Thetford Mines Ophiolite, Québec, Canada. Economic Geology, v. 104, pp. 997-1018. doi:org/ 10.2113/econgeo.104.7.997.

Page, N.J., Cassard, D., and Haffty, J., 1982, Palladium, platinum, rhodium, ruthenium, and iridium in chromitites from the Massif du Sud and Tiebaghi massif, New Caledonia. Economic Geology, v. 77, pp. 1571-1577. doi:org/10.2113/gsecongeo.77.6.1571.

Page, N.J., and Talkington, R.W., 1984, Palladium, Platinum, Rhodium, Ruthenium and Iridium in Peridotites and Chromitites From Ophiolite Complexes in Newfoundland. Canadian Mineralogist, v. 22, pp. 137-149.

Pal, T., 2011, Petrology and geochemistry of the Andaman ophiolite: melt-rock interaction in a suprasubduction-zone setting. Journal of the 
Geological Society, v. 168, pp. 1031-1045. doi:org/10.1144/0016-76492009152.

Parkinson, I.J., and Arculus, R.J., 1999, The redox state of subduction zones: insights from arc-peridotites. Chemical Geology, v. 160, pp. 409-423. doi:org/10.1016/s0009-2541(99)00110-2.

Parkinson, I.J., and Pearce, J.A., 1998, Peridotites from the Izu-BoninMariana forearc (ODP Leg 125): Evidence for mantle melting and melt-mantle interaction in a supra-subduction zone setting. Journal of Petrology, v. 39, pp. 1577-1618. doi:org/10.1093/petroj/39.9.1577.

Pedersen, R.B., Johannesen, G.M., and Boyd, R., 1993, Stratiform platinum-group element mineralizations in the ultramafic cumulates of the Leka ophiolite complex, central Norway. Economic Geology, v. 88, pp. 782-803. doi:org/10.2113/gsecongeo.88.4.782.

Prichard, H.M., and Lord, R.A., 1993, An overview of the PGE concentrations in the Shetland ophiolite complex. Geological Society of London, Special Publications, 76, pp. 273-294. doi:org/10.1144/gsl.sp. 1993. 076.01.13.

Prichard, H.M., Neary, C.R., Fisher, P.C., and O'Hara, M.J., 2008, PGErich podiform chromitites in the Al 'Ays ophiolite complex, Saudi Arabia: An example of critical mantle melting to extract and concentrate PGE. Economic Geology, v. 103, pp. 1507-1529. doi:org/10.2113/gsecongeo.103.7.1507.

Proenza, J.A., Gervilla, F., Melgarejo, J.C., and Bodinier, J.L., 1999, A1and $\mathrm{Cr}$-rich chromitites from the Mayari-Baracoa ophiolitic belt (eastern Cuba): consequence of interaction between volatile-rich melts and peridotites in suprasubduction mantle. Economic Geology, v. 94, pp. 547-566. doi:org/10.2113/gsecongeo.94.4.547.

Proenza, J.A., Zaccarini, F., Escayola, M., Cábana, C., Schalamuk, A., and Garuti, G., 2008, Composition and textures of chromite and platinumgroup minerals in chromitites of the western ophiolitic belt from Pampean Ranges of Córdoba, Argentina. Ore Geology Reviews, v. 33, pp. 32-48. doi:org/10.1016/j.oregeorev.2006.05.009.

Qiu, T., Yang, J., Milushi, I., Wu,W., Mekshiqi, N., Xiong, F., Zhang, C., and Shen, T., 2018, Petrology and PGE Abundances of High-Cr and High-Al Podiform Chromitites and Peridotites from the Bulqiza Ultramafic Massif, Eastern Mirdita Ophiolite, Albania. Acta Geologica Sinica, v. 92, pp. 1063-1081. doi:org/10.1111/1755-6724.13592.

Reagan, M.K., Ishizuka, O., Stern, R.J., Kelley, K.A., Ohara, Y., BlichertToft, J., Bloomer, S.H., Cash, J., Fryer, P., Hanan, B.B., HickeyVargas, R., Ishii, T., Kimura, J.I., Peate, D.W., Rowe, M.C., and Woods, M., 2010, Fore-arc basalts and subduction initiation in the Izu-Bonin-Mariana system. Geochemistry, Geophysics, Geosystems, v. 11, pp. 1-17. doi:org/10.1029/2009gc002871.

Roberts, S., and Neary, C., 1993, Petrogenesis of Ophiolitic Chromitite. Geological Society of London, Special Publication, 76, pp. 257-272. doi:org/10.1144/gsl.sp.1993.076.01.12.

Robinson, P. T., Zhou, M.F., Malpas, J., and Bai, W.J., 1997, Podiform chromitites; their composition, origin and environment of formation. Episode, v. 20, pp. 247-252.

Robinson, P.T., Bai, W.J., Malpas, J., Yang, J.S., Zhou, M.F., Fang, Q.S., Hu, X.F., Cameron, S., and Staudigel, H., 2004, Ultra-high pressure minerals in the Luobusa Ophiolite, Tibet, and their tectonic implications. Geological Society of London, Special Publications, 226, pp. 247-271. doi:org/10.1144/gsl.sp.2004.226.01.14.

Rollinson, H., 2005, Chromite in the mantle section of the Oman ophiolite: A new genetic model. Island Arc, v. 14, pp. 542-550. doi:org/ 10.1111/j.1440-1738.2005.00482.x.

Rollinson, H., 2008, The geochemistry of mantle chromitites from the northern part of the Oman ophiolite: Inferred parental melt compositions. Contributions to Mineralogy and Petrology, v. 156, pp. 273-288. doi:org/10.1007/s00410-008-0284-2.

Rollinson, H., and Adetunji, J., 2013, Mantle podiform chromitites do not form beneath mid-ocean ridges: A case study from the Moho transition zone of the Oman ophiolite. Lithos, v. 177, pp. 314-327. doi:org/10.1016/ j.lithos.2013.07.004.
Rollinson, H., and Adetunji, J., 2015, The geochemistry and oxidation state of podiform chromitites from the mantle section of the Oman ophiolite. A review. Gondwana Research, v. 27, pp. 543-554. doi:org/ 10.1016/j.gr.2013.07.013.

Sack, R.O., and Ghiorso, M.S., 1991, Chromian spinels as petrogenetic indicators; thermodynamics and petrological applications. American Mineralogist, v. 76, pp. 827-847.

Schaltegger, U., Zeilinger, G., Frank, M., and Burg, J.P., 2002, Multiple mantle sources during island arc magmatism: $\mathrm{U}-\mathrm{Pb}$ and $\mathrm{Hf}$ isotopic evidence from the Kohistan arc complex, Pakistan. Terra Nova, v. 14, pp. 461-468. doi:org/10.1046/j.1365-3121.2002.00432.x.

Sun, M., Jain, J.S., Zhou, M.F., and Kerrich, R., 1993, A Procedural Modification for Enhanced Recovery of Precious Metals (Au, Pge) Following Nickel Sulphide Fire Assay and Tellurium Co-Precipitation - Applications for Analysis of Geological Samples By Inductively Coupled Plasma Mass Spectrometry. Canadian Journal of Applied Spectroscopy, v. 38, pp. 103-108.

Sun, Y., and Sun, M., 2005, Nickel sulfide fire assay improved for pre-concentration of platinum group elements in geological samples: A practical means of ultra-trace analysis combined with inductively coupled plasma-mass spectrometry. Analyst, v. 130, pp. 664-669. doi:org/10.1039/ b416844e.

Tamura, A., Morishita, T., Ishimaru, S., Hara, K., Sanfilippo, A., and Arai, S., 2016, Compositional variations in spinel-hosted pargasite inclusions in the olivine-rich rock from the oceanic crust-mantle boundary zone. Contributions to Mineralogy and Petrology, v. 171, pp. 1-14. doi:org/ 10.1007/s00410-016-1245-9.

Tian, Y., Yang, J., Robinson, P.T., Xiong, F., Li, Y., Zhang, Z., Liu, Z., Liu, F., and Niu, X., 2015, Diamond Discovered in High-Al Chromitites of the Sartohay Ophiolite, Xinjiang Province, China. Acta Geologica Sinica, v. 89, pp. 332-340. doi:org/10.1111/1755-6724.12433.

Tsoupas, G., and Economou-Eliopoulos, M., 2008, High PGE contents and extremely abundant PGE-minerals hosted in chromitites from the Veria ophiolite complex, northern Greece. Ore Geology Reviews, v. 33, pp. 3-19. doi:org/10.1016/j.oregeorev.2006.10.008.

Uysal, I., Akmaz, R.M., Kapsiotis, A., Demir, Y., Saka, S., Avci, E., and Müller, D., 2015, Genesis and geodynamic significance of chromitites from the Orhaneli and Harmancik ophiolites (Bursa, NW Turkey) as evidenced by mineralogical and compositional data. Ore Geology Reviews, v. 65, pp. 26-41. doi:org/10.1016/j.oregeorev.2014.08.006.

Uysal, I., Sadiklar, M.B., Tarkian, M., Karsli, O., and Aydin, F., 2005, Mineralogy and composition of the chromitites and their platinum-group minerals from Ortaca (Muğla-SW Turkey): Evidence for ophiolitic chromitite genesis. Mineralogy and Petrology, v. 83, pp. 219-242. doi:org/10.1007/ s00710-004-0063-3.

Uysal, I., Tarkian, M., Sadiklar, M.B., Zaccarini, F., Meisel, T., Garuti, G., and Heidrich, S., 2009a, Petrology of Al- and Cr-rich ophiolitic chromitites from the Muğla, SW Turkey: Implications from composition of chromite, solid inclusions of platinum-group mineral, silicate, and basemetal mineral, and Os-isotope geochemistry. Contributions to Mineralogy and Petrology, v. 158, pp. 659-674. doi:org/10.1007/s00410-009-0402-9.

Uysal, I., Zaccarini, F., Sadiklar, M.B., Bernhardt, H.J., Bigi, S., and Garuti, G., 2009b, Occurrence of rare Ru-Fe-Os-Ir-oxide and associated Platinum-group minerals (PGM) in the chromitite of Muğla ophiolite, SW-Turkey. Neues Jahrbuch für Mineralogie - Abhandlungen, v. 185, pp. 323-333. doi:org/10.1127/0077-7757/2009/0131.

Wan, Z., Coogan, L.A., and Canil, D., 2008, Experimental calibration of aluminum partitioning between olivine and spinel as a geothermometer. American Mineralogist, v. 93, pp. 1142-1147. doi:org/10.2138/am.2008.2758.

Wu, W., Yang, J., Ma, C., Milushi, I., Lian, D., and Tian, Y., 2017, Discovery and Significance of Diamonds and Moissanites in Chromitite within the Skenderbeu Massif of the Mirdita Zone Ophiolite, West Albania. Acta Geologica Sinica, v. 91, pp. 882-897. doi:org/10.1111/ 1755-6724.13316.

Wilson, M., 1989, Review of Igneous Petrogenesis: A Global Tectonic 
Approach. Terra Nova, v. 1, pp. 218-222. doi:org/10.1111/j.13653121.1989.tb00357.x.

Xiong, F., Yang, J., Liu, Z., Guo, G., Chen, S., Xu, X., Li, Y., and Liu, F., 2013, High Cr and high-Al chromitite found in western Yarlung-Zangbo suture zone in Tibet. Acta Petrologica Sinica, v. 29, pp. 1878-1908.

Xiong, F., Yang, J., Robinson, P.T., Xu, X., Liu, Z., Zhou, W., Feng, G., Xu, J., Li, J., and Niu, X., 2017, High-Al and high-Cr podiform chromitites from the western Yarlung-Zangbo suture zone, Tibet: Implications from mineralogy and geochemistry of chromian spinel, and platinumgroup elements. Ore Geology Reviews, v. 80, pp. 1020-1041. doi:org/ 10.1016/j.oregeorev.2016.09.009.

Xiong, Q., Griffin, W.L., Zheng, J.P., O'Reilly, S.Y., Pearson, N.J., Xu, B., and Belousova, E.A., 2016, Southward trench migration at $~ 130-120$ Ma caused accretion of the Neo-Tethyan forearc lithosphere in Tibetan ophiolites. Earth and Planetary Science Letters, v. 438, pp. 57-65. doi:org/ 10.1016/j.epsl.2016.01.014.

Yamamoto, S., Komiya, T., Hirose, K., and Maruyama, S., 2009, Coesite and clinopyroxene exsolution lamellae in chromites: In-situ ultrahighpressure evidence from podiform chromitites in the Luobusa ophiolite, southern Tibet. Lithos, v. 109, pp. 314-322. doi:org/10.1016/j.lithos. 2008.05.003.

Yang, J., Robinson, P. T., and Dilek, Y., 2014, Diamonds in Ophiolites: A little-Known Diamond Occurrence Diamonds on Earth. Elements, v. 10, pp. 123-126.

Yang, J., Robinson, P. T., and Dilek, Y., 2015, Diamond-bearing ophiolites and their geological occurrence. Episodes, v. 38. pp. 344-364. doi:org/ 10.18814/epiiugs/2015/v38i4/82430.

Yang, J., Xu, X., Li, Y., Li, J., Ba, D., Rong, H., and Zhang, Z., 2011, Diamonds recovered from peridotites of the Purang ophiolite in the Yarlung-Zangbo Suture of Tibet: a proposal for a new type of diamond occurrence. Acta Petrologica Sinica, v. 27, pp. 3171-3178.

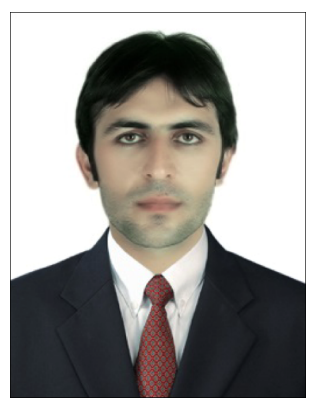

Zaheen Ullah is a $\mathrm{PhD}$ student at Faculty of Earth Resource China University of Geosciences Wuhan, China. His $\mathrm{PhD}$ research interest is in Mineralogy, Petrology and Economic Geology.
Yang, J., Dobrzhinetskaya, L., Bai, W., Fang, Q., Robinson, P.T., Zhang, J., and Green, H.W., 2007, Diamond- and coesite-bearing chromitites from the Luobusa ophiolite, Tibet. Geology, v. 35, pp. 875-878. doi:org/10.1130/g23766a.1.

Zaccarini, F., Garuti, G., Proenza, J.A., Campos, L., Thalhammer, O.A.R., Aiglsperger, T., and Lewis, J.F., 2011, Chromite and platinum group elements mineralization in the Santa Elena Ultramafic Nappe (Costa Rica): Geodynamic implications. Geologica Acta, v. 9, pp. 407-423. doi:org/10.1344/105.000001696.

Zhou, M.F., and Robinson, P.T., 1997, Origin and tectonic environment of podiform chromite deposits. Economic Geology, v. 92, pp. 259-262. doi:org/10.2113/gsecongeo.92.2.259.

Zhou, M.F., Robinson, P.T., and Bai, W.J., 1994, Formation of podiform chromitites by melt/rock interaction in the upper mantle. Mineralium Deposita, v. 29, pp. 98-101. doi:org/10.1007/bf03326400.

Zhou, M.F., Robinson, P.T., Malpas, J., and Li, Z., 1996, Podiform chromitites in the Luobusa ophiolite (Southern Tibet): Implications for meltrock interaction and chromite segregation in the upper mantle. Journal of Petrology, v. 37, pp. 3-21. doi:org/10.1093/petrology/37.1.3.

Zhou, M.F., Robinson, P.T., Su, B.X., Gao, J.F., Li, J.W., Yang, J.S., and Malpas, J., 2014, Compositions of chromite, associated minerals, and parental magmas of podiform chromite deposits: The role of slab contamination of asthenospheric melts in suprasubduction zone environments. Gondwana Research, v. 26, pp. 262-283. doi:org/10.1016/j.gr. 2013.12.011

Zhou, M.F., Sun, M., Keays, R.R., and Kerrich, R.W., 1998, Controls on platinum-group elemental distributions of podiform chromitites: A case study of high-Cr and high-Al chromitites from Chinese orogenic belts. Geochimica et Cosmochimica Acta, v. 62, pp. 677-688. doi:org/ 10.1016/s0016-7037(97)00382-7.

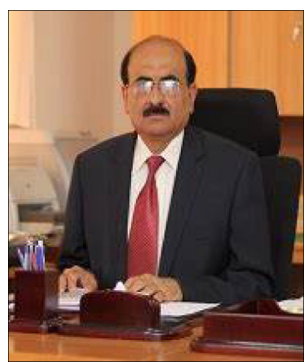

Muhammad Tahir Shah is currently working as a Vice Chancellor of FATA University, Tribal Subdivision Darra Kohat, Pakistan. $\mathrm{He}$ is Fulbright Post-Doctoral Fellowship awardee from University of Nevada, USA and Commonwealth Post-Doctoral Fellowship awardee from University of Leicester, UK. He received his $\mathrm{PhD}$ degree in Economic Geology and Geochemistry from School of Earth Sciences, University of South Carolina Columbia, USA. His research interest includes Mineralogy, Petrology, Geochemistry and different Ore Mineralization. 